\title{
Breast cancer treatment by transplantations of dendritic cells and cytokine-induced killer cells: An update on clinical trials
}

\author{
Hieu Trong Ngo ${ }^{1,2}$, Phuc Van Pham ${ }^{1,2,3,4, *(1)}$
}

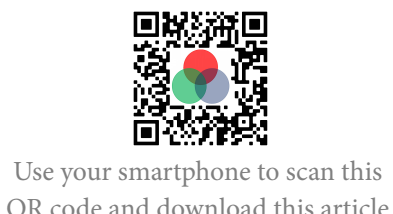

QR code and download this article
${ }^{1}$ Stem Cell Institute, University of Science Ho Chi Minh City, Viet Nam

${ }^{2}$ Viet Nam National University Ho Chi Minh City, Ho Chi Minh City, Viet Nam

${ }^{3}$ Laboratory of Stem Cell Research and Application, University of Science Ho Chi Minh City, Viet Nam

${ }^{4}$ Laboratory of Cancer Research, University of Science Ho Chi Minh City, Viet Nam

\section{Correspondence}

Phuc Van Pham, Stem Cell Institute University of Science Ho Chi Minh City, Viet Nam

Viet Nam National University Ho Chi Minh City, Ho Chi Minh City, Viet Nam

Laboratory of Stem Cell Research and Application, University of Science Ho Chi Minh City, Viet Nam

Laboratory of Cancer Research, University of Science Ho Chi Minh City, Viet Nam

Email: phucpham@sci.edu.vn

History

- Received: Aug 15, 2021

- Accepted: Nov 15, 2021

- Published: Nov 30, 2021

DOI : 10.15419/bmrat.v8i11.707

Check for updates

\section{Copyright}

(๑) Biomedpress. This is an openaccess article distributed under the terms of the Creative Commons Attribution 4.0 International license.

\begin{abstract}
Breast cancer is the world's most common cancer in women and is the leading cause of their cancerrelated mortality. Its early diagnosis with conventional therapies such as surgery, chemotherapy, and radiotherapy can give good results in most breast cancer patients. However, these therapies provide poor outcomes in metastatic breast cancers or late-stage breast cancer. Therefore, as another effort for breast cancer treatment, immunotherapy is now considered the fourth-line cancer treatment besides conventional therapies. In this article, we focus on breast cancer treatment by transplantation of cytokine-induced killer cells (CIKs) and dendritic cells (DCs). While CIKs are effector cells that can directly attack and kill breast cancer cells, DCs support other immune cells in including CIKs in antitumor activities. Although transplantation of CIKs or DCs alone gave limited results in breast cancer treatment, the combination of CIKs and DCs in current clinical trials demonstrated significant results. Thus, we propose that CIK-DC therapy will emerge as a new option for breast cancer treatment soon.
\end{abstract}

Key words: Breast cancer, Cytokine induced killer cell, DC-CIK therapy, Dendritic cell, Immunotherapy

\section{INTRODUCTION}

Breast cancer is the world's most common cancer in women and is the leading cause of their cancer-related mortality. It can usually affect women of all ages. In the US itself, breast cancer incidence in women is up by $30 \%$, recorded in $2019^{1}$. During $1996-2015$, about 14,222 new breast cancer cases were reported (including 13,948 women, accounting for 98\%), and more than half were diagnosed with stage II while stage III and IV were about $26 \%{ }^{2}$.

Early diagnosis of breast cancer combined with conventional therapy such as surgery, chemotherapy, and radiotherapy is the most common strategy. However, due to the heterogeneous nature of breast cancer and the incidence of metastasis, it remains incurable. Therefore, in the efforts against cancer, immunotherapy has emerged as the fourth line of cancer treatment besides conventional therapy. Immunotherapy harnesses the complexity of the natural immune system to fight cancer, either actively or passively; the strategies aim to boost host immunity to fight cancer again. Massive research on immunotherapy has produced many promising clinical results, including treatment with checkpoint inhibitory, cytokine, and adoptive cell therapies ${ }^{3,4}$. Additionally, the breakthrough of using anti-PD-1 and anti-PD-L1 antibodies in treatment with metastatic, triple-negative breast cancer patients has illuminated the field of immunotherapy for breast cancer treatment ${ }^{5}$.

Adoptive cell immunotherapy offers an approach that selectively targets cancer with high efficiency and low risk of side effects ${ }^{6}$. Cell immunotherapy is a promising strategy aimed at improving the antitumor activity of the immune system. Based on the concept of harnessing the immune system, several concepts have been developed for cell-based immunotherapy approach, including adoptive cell therapy with LAK, TIL, CAR-T, NK, and CIK or cancer vaccine with DCs-based immunotherapy.

In this review, we focus on studying cytokine-induced killer cells (CIK) and dendritic cells (DCs) in breast cancer treatment. Cell immunotherapy is a promising strategy aimed at improving the antitumor activity of an immune system.

\section{CYTOKINE-INDUCED KILLER CELLS \& DENDRITIC CELLS FOR BREAST CANCER TREATMENTS}

CIKs and their cytotoxic mechanisms toward tumor cells

\section{What are CIKs}

Cytokine-induced killer cells (CIKs) are a heterogeneous population characterized by the frequency 
of three populations: $\mathrm{CD}^{+} \mathrm{CD}^{+} 6^{+}$(NK-like $\mathrm{T}$ ), $\mathrm{CD}^{+}{ }^{+} \mathrm{CD} 56^{-}$(T lymphocytes), and $\mathrm{CD} 3^{-} \mathrm{CD} 56^{+}$ (NK cells). This population is produced only by the in vitro culture of MNCs supplemented with cytokines. The first protocol for CIK production was introduced by Schmidt-Wolf et al. in the $1990 \mathrm{~s}^{7}$.

\section{How to produce CIKs?}

CIK cells can be easily produced in ex-vivo conditions using MNCs from bone marrow, peripheral blood, or umbilical cord blood in combination with supplements of interferon-gamma (IFN- $\gamma$ ) and interleukin2 (IL-2) with antibody-CD3 clone OKT3 over shortterm of $2-3$ weeks. The culture condition of CIK was modified from the LAK production protocol adding $1000 \mathrm{U} / \mathrm{ml}$ of INF- $\gamma 24$ hours before culture in the condition of anti-CD3 and IL- $2^{8}$. The addition of IFN-g significantly enhances CIK cytotoxicity compared to the LAK culture method. Indeed, IFN-g plays a role in inducing IL-12 production by activating monocytes ${ }^{9,10}$. Furthermore, compared to LAK cells, CIK cells showed a higher ex-vivo expansion and prolonged in-vivo antitumor effect without exogenous cytokine IL-2 ${ }^{11,12}$

The ratios of the three different cell populations inside a CIK population are different between culture and inducible protocol. Generally, a CIK population is characterized by average $70-80 \%$ of $\mathrm{CD}^{+}$cells, $\mathrm{CD}^{+}{ }^{+} \mathrm{CD}^{+}{ }^{+}$cells over $60-80 \%$ and $\mathrm{CD} 3^{+} \mathrm{CD} 56^{+}$ cells over $20-30 \%{ }^{13}$. Antitumor effects of the CIK population are best seen in $\mathrm{CD}_{3}{ }^{+} \mathrm{CD} 56^{+}$population, a subset of $\mathrm{CD}^{+} \mathrm{T}$ lymphocytes that co-express natural killer cell protein $\mathrm{CD} 56^{14,15}$. The $\mathrm{CD} 3^{+} \mathrm{CD} 56^{+}$ subset is derived from $\mathrm{CD}^{+}{ }^{+} \mathrm{CD} 8^{+} \mathrm{T}$ lymphocytes, acquiring the terminally differentiated effector phenotype and granular structure of NK cells and higher levels of secreted antitumor cytokine IFN- $\gamma$, TNF$\alpha$, Granzyme B/Perforin ${ }^{15-17}$. In-vitro expandedCIK significantly increased $\mathrm{CD}^{+}{ }^{+} \mathrm{CD} 8^{+} \mathrm{T}$ cells and $\mathrm{CD}^{+}{ }^{+} \mathrm{CD} 56^{+}$NK-like T cells ${ }^{15,17}$.

\section{Antitumor activity of CIK population}

The antitumor activities of CIK population are acquired from the activities of three different cells inside. All subsets of $\mathrm{CIK}$ populations $\left(\mathrm{CD} 3{ }^{+} \mathrm{CD} 56^{-}\right.$, $\mathrm{CD}^{+}{ }^{+} \mathrm{CD} 56^{+}$, and $\mathrm{CD} 3{ }^{-} \mathrm{CD} 56^{+}$) display antitumor activity through various mechanisms (Figure 1).

$\mathrm{CD}^{+}{ }^{+} \mathrm{CD}_{56}{ }^{+}$cell subset is capable of inducing MHCunrestricted antitumor cytotoxicity ${ }^{14,18}$. Indeed, CIKs also display their cytotoxic capacity in case of blocking of their receptors $(\mathrm{CD} 2, \mathrm{CD} 3, \mathrm{CD} 8, \mathrm{CD} 28$, CD56, very late antigen [VLA-4], T-cell receptor
[TCR] $\alpha \beta$, MHC class I and II) by antibodies. The cytotoxic function of these populations heavily depends on engaging several activation receptors and releasing Granzyme-B/Perforin proteins from CIKs ${ }^{19}$. As a result of co-expression of $\mathrm{NK}$ and $\mathrm{T}$ cell markers, Pievani et al. (2011) suggested that the $\mathrm{CD}^{+}{ }^{+} \mathrm{CD} 56^{+}$ cells acquire dual cytotoxic functions ${ }^{16}$, which stem from NK-cytotoxic functions and T-cell cytotoxic mechanisms. Antitumor activities of CIK cells require the direct interaction between CIK and tumor cells through surface markers ${ }^{16,20}$. These interactions induce the release of granzyme $\mathrm{B}$ and perforin to mediate CIK-related killing function and promote IFN- $\gamma$ and TNF- $\alpha$ production $^{21}$. The interactions via receptors between CIKs and tumor cells are not well-understood; some recent studies suggested four main interactions between CIKs and tumor cells. The first interaction is performed by receptor leukocyte function-associated antigen-1 (LFA-1) on the CIKs with their ligands in tumor cells (ICAM-1, -2, and -3). Indeed, if the LFA-1 or ICAM-1 is blocked, the cytotoxic potential is significantly reduced ${ }^{15,22,23}$. The second interaction that plays an essential role in tumor recognition by CIK cells is the natural killer group $2 \mathrm{D}$ (NKG2D) receptor on CIK cells and their ligands in tumor cells. NKG2D receptor is a member of the c-type lectin-activating receptor family expressed in the NK cells and NKG2D ligands: stressinducible molecules on both solid and hematologic tumors, such as the MHC class I-related molecules A and $\mathrm{B}$ (MIC A/B) and members of the UL16-binding protein family (ULBP1-4) expressed in tumor cells. Interestingly, NKG2D ligands appear to express a pattern relatively restricted to malignant tumors ${ }^{24,25}$. The expression of NKG2D receptors is involved in the high dose of IL-2 presenting in the culture medium. Besides IL-2, IL-15 also seems to be a target recognition of NKG2D ${ }^{26}$. The third interaction relates to the expression of CD56 expressed on CIKs with their ligands in tumor cells. Introna et al. suggested that CD56 plays a role in tumor recognition and cytotoxicity of CIK cells. Therefore, when antibodies blocked CD56 in the CIKs, the cytolysis of CIKs reduced $^{27,28}$. The fourth interaction relate to Fas ligand (FasL) highly expressed in CIKs and Fas on tumor cells $^{8,29}$. In a recent study, Meng et al. analyzed the transcriptomic atlas of CIKs and confirmed the high expression of FasL in $\mathrm{CIKs}^{30}$. The direct contact of FasL on Fas triggers Fas-dependent apoptosis mechanism in tumor cells ${ }^{15,16,19}$. Recently, the interactions of NKp30 and DNAM-1 expressed in CIKs with their ligands on tumor cells play a role in antitumor cytotoxicity of CIKs ${ }^{16}$. 


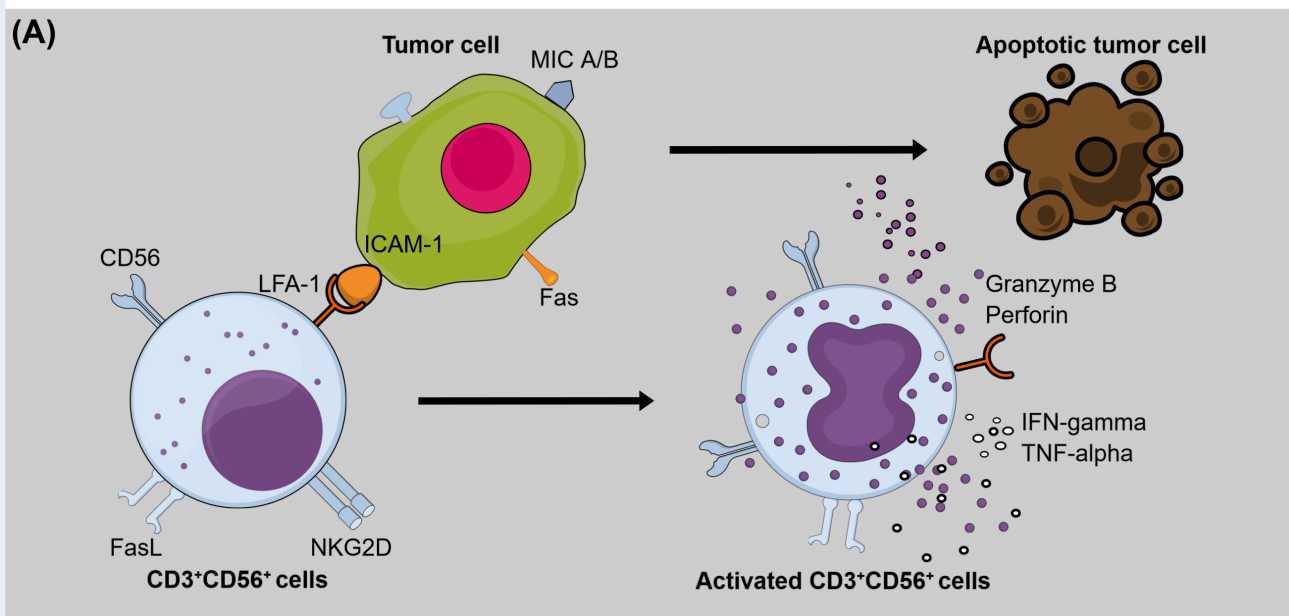

(B)

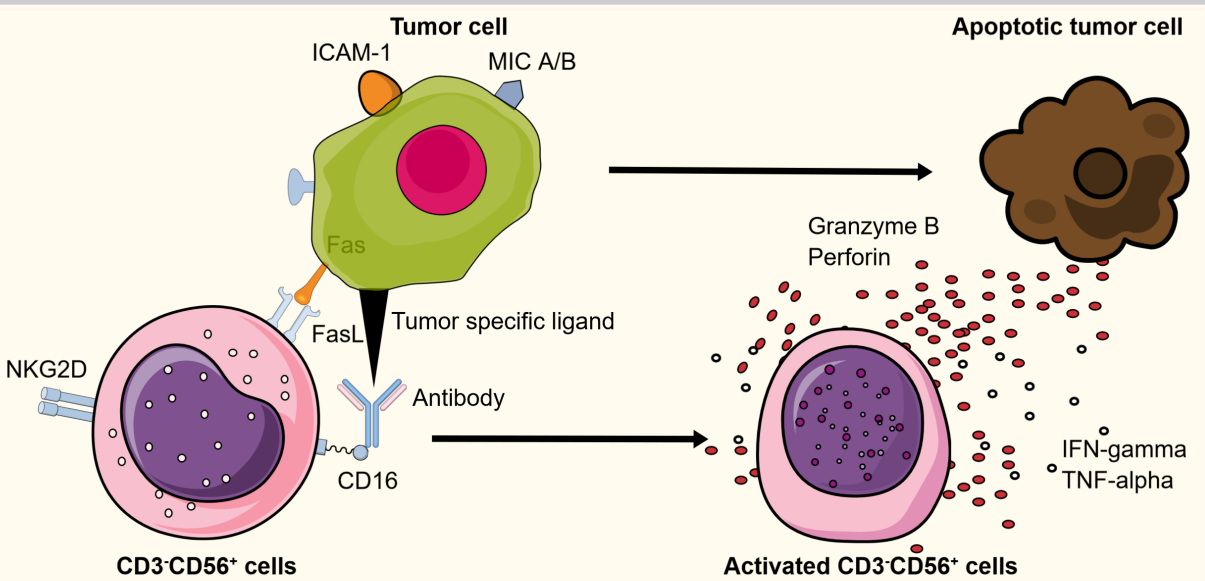

(C)
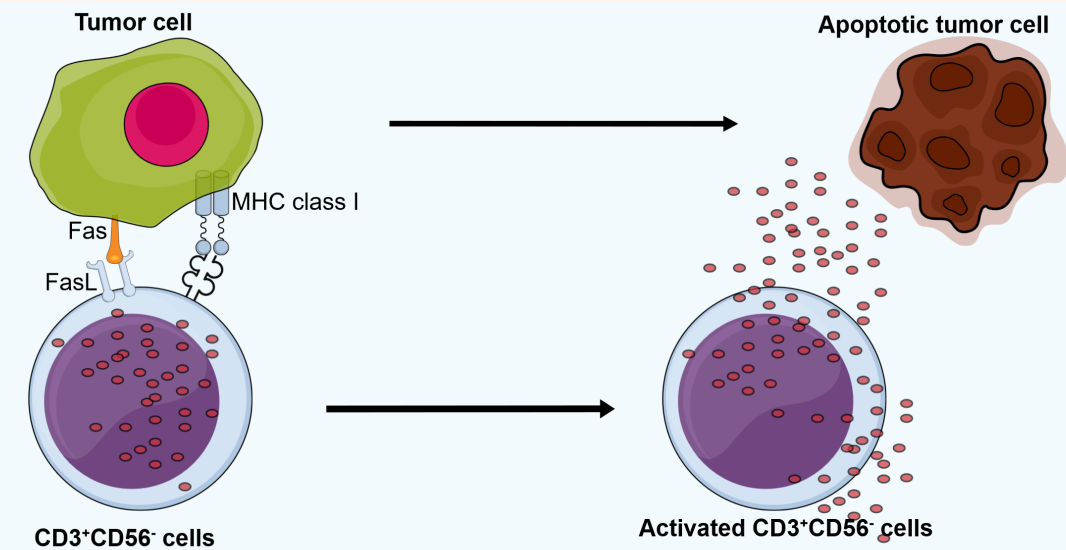

Figure 1: The antitumor activities of $\mathrm{CIK}$ population are acquired from the activities of three different cells inside $\left(\mathrm{CD}^{+}{ }^{\mathrm{CD} 56^{-}}, \mathrm{CD}^{+} \mathrm{CD}^{-} 6^{+}\right.$, and $\left.\mathrm{CD}^{-} \mathrm{CD}^{-} 6^{+}\right)$. (A) The $\mathrm{CD}^{+}{ }^{+} \mathrm{CD} 56^{+}$cell population can kill the tumor cells by releasing Gramzym B/Perforin after interacting with tumor cells through surface markers. (B) The $\mathrm{CD} 3 \mathrm{CD}^{+} 6^{+}$cell population displays the antitumor activities similar to NK cells, while $(\mathbf{C})$ the $\mathrm{CD} 3^{+} \mathrm{CD} 56^{-}$cell population exhibits the antitumor activities similar to $\mathrm{T}$ cytotoxic cells.

https://doi.org/10.6084/m9.figshare.17104232.v1 
Some recent studies revealed that CIK could perform the antibody-dependent cell cytotoxicity mediated by the expression of CD16. This observation is different between groups. Some studies suggested a subset of $\mathrm{CD}^{+}{ }^{+} \mathrm{CD} 56^{+} \mathrm{CD} 16^{+}$in the population of $\mathrm{CD}^{+}{ }^{+} \mathrm{CD} 56+{ }^{31-34}$, while other groups did not detect the expression of this protein in the $\mathrm{CD} 3{ }^{+} \mathrm{CD} 56^{+}$ population 11,15,35. Cappuzzello et al. suggested that the expression of CD16 in the CIK population was donor-dependent ${ }^{8}$. In a study of 60 samples, the $\mathrm{CD}^{+}{ }^{+} \mathrm{CD} 56{ }^{+} \mathrm{CD} 16^{+}$population ranged from $2.3 \%$ $-54.2 \%$ (mean $16 \pm 13.3 \%$ ). In vitro study and $\mathrm{mAbs}$ enhanced the specific lysis rate of CIK cells against EGFR- and Her-expressed cell lines. In TBNCPatient-Derived Xenograft (PDX) models, treatment combining monoclonal antibody (mAb) and CIK significantly prolonged survival and reduced tumor volume. According to tumor section analyses, the combination also resulted in a higher infiltration of immune cells in the tumor ${ }^{36}$.

\section{In-vivo antitumor activity of CIKs}

In a preclinical study, infused-allogeneic CIK cells able to locate and increase in spleen and cervical lymph nodes and remain in tumor site for up to 21 suggested prolonged antitumor effects. In regard to graft versus host disease (GVHD), models, dose up to $20.10^{6}$ allogeneic CIK cells was tolerated well compared to naïve $\mathrm{T}$ cell infusion, which quickly developed severe acute GVHD ${ }^{18}$. CIK cells demonstrated antitumor activity toward a wide range of cancer cell lines and freshly isolated cancer cells. Furthermore, numerous studies proved CIK's ability to treat both hematologic and solid tumors ${ }^{13,20,21,37,38}$. Recently, Capellero et al. published a preclinical study; the CIK cells from EOC patients efficiently killed patient-derived ovarian cancer cell lines (pdOVC), with no difference between autologous and allogeneic targets ${ }^{39}$. Also, the study indicated that CIK cells also efficiently killed chemotherapy-survived pdOVC; the killing ability was superior due to the high expression of stress ligand in tumor cells after being treated with carboplatin. In in-vivo models, CIK infusion resulted in high necrotic areas and a high rate of CIK infiltration. In a study with breast cancer cell line MCF7, CIK strongly inhibits proliferation of both radioresistant and normal MCF-7 cells ${ }^{17,40}$.

Clinically, in 2020, Ying Zhang and Schmidt-Wolf published an updated international registry over the past ten years of CIK immunotherapy ${ }^{13}$. A total of 106 clinical trials was registered through IRCC; 4,889 patients with more than 30 types of cancers received
CIK treatment along with/without conventional therapy. Treatment with CIK-based therapy significantly improves mPFS and mOS of patients. Patients' immune system was significantly altered: $\mathrm{CD} 3{ }^{+} \mathrm{CD} 56^{+}$, $\mathrm{CD}^{+}{ }^{+} \mathrm{CD} 8{ }^{+}, \mathrm{CD}^{+} / \mathrm{CD}^{+}$population ratio were elevated while T-reg population $\mathrm{CD} 4{ }^{+} \mathrm{CD} 25^{+} \mathrm{FoxP}^{+}$ was decreased. Also, the level of Th-1 associated cytokine was increased after CIK treatment. In terms of safety, CIK treatment-related side effects were mostly grade I and II such as fever, chills, fatigue, headache, and skin rash. The incidence of grade III-IV toxicities was rare in the CIK treatment group. Infusion of allogeneic CIK was related to acute and chronic GVHD; however, patients showed good -tolerance the immunosuppressive regimen. The CIK treatment reported a higher Karnofsky score (KPS), better appetite, improved sleep, weight gain, and pain relief.

\section{DCs and their cytotoxic mechanisms toward tumor cells \\ What dendritic cells are?}

Dendritic cells (DCs) are known as professional antigen-presenting cells (APCs). The DCs' ability to present antigen attracts attention as carriers for cancer vaccine approaches ${ }^{41}$. In the body, DCs are activated and matured in response to the environmental stimulator. The activation of DCs further mediates $\mathrm{T}$ cell activation through the engagement of $\mathrm{MHC}$ class I/II and co-stimulation with cytokines. The DC-based vaccinations inhibit tumor growth by altering host lymphocyte composition. Ex-vivo expanded TAA-loaded DCs have been widely approached in a clinical study for targeting tumor and boosting specific-targeting immune response. Over the past two decades, DC-based therapy represents a feasible approach to elicit antitumor immunity while remaining safe and well-tolerated in patients.

\section{How to produce DCs?}

Current approaches of DC-based immunotherapy include the use of isolated $\mathrm{CD} 14^{+}$monocytes or CD $34^{+}$ HPC from blood or bone marrow ${ }^{42}$. Several protocols have been developed using unstimulated DCs, ex-vivo matured DCs or cell-lysate/TAA-pulsed DCs, in-situ DC vaccination, and DC-derived exosomes ${ }^{43}$. The first generation used tumor antigen-loaded immature DCs and achieved poor clinical response with only 3.3\% tumor regression. The second-generation DC vaccines used matured monocyte-derived DCs, and the treatment reached $8-15 \%$ objective response rates with the median OS increasing by $\sim 20 \%$ in some studies ${ }^{44}$. 


\section{The roles of DCs in anti-tumors}

Unlike CIKs - effector cells that can directly attack cancer cells and kill them - DCs are antigenpresenting cells so that they indirectly strengthen the antitumor process of the immune system. However, they play an essential role in immune response in cancer treatment. Indeed, cancer cells usually escape from the immune surveillance in cancer patients, especially the sub-population of cancer stem cells inside. The effector $\mathrm{T}$ cells inside these patients cannot recognize cancer to kill them. DCs, in this case, will activate the T cells (both $\mathrm{CD}^{+}{ }^{+}$and $\mathrm{CD} 8^{+}$cells). They can give some essential boost to immune responses in antitumor activity:

DCs enable $\mathrm{CD}^{+}{ }^{+} \mathrm{T}$ cells to activate $\mathrm{B}$ and $\mathrm{CD} 8^{+}$ cells. This process is based on the interaction between DCs and CD4 ${ }^{+} \mathrm{T}$ cells through CD40. The CD40 in DCs will interact with the CD40 ligand in T cells leading to DC activation. In the activated state, DCs can prime $\mathrm{T}$ cells and up-regulate the expression of some co-stimulatory molecules and produce IL-12. Then, IL-12 causes polarization in naïve $\mathrm{CD} 4^{+}$cells toward Th1 cells or Th 2 cells. Th1 cells and Th2 cells will promote $\mathrm{CD} 8{ }^{+}$cells and B cells through some cytokines (IL-2, IL-4, IL-5, IL-13, and IFN-g).

DCs also cross-talk with NKs and play a pivotal role in the innate immune response against cancer ${ }^{45}$. DCs interact with NKs via CXCR3 in the draining lymph nodes in a "touch and go" mode lasting from 300 s to $4 \mathrm{~h}^{46}$. As a result, DCs will produce IL-12, IL-18, IL27, type I IFNs, and IL-15, PGE2. These cytokines directly affect $\mathrm{NK}$ cells, triggering $\mathrm{NK}$ cell proliferation and activating NK cells. The activated NK cells leave the lymph node, infiltrate tumors, and attack cancer cells in the tumors.

\section{In-vivo antitumor activity of DCs}

Clinical trials of DC vaccination showed promising results. In the role of APC, DCs are used to present tumor antigens to other immune cells. Therefore, both tumor-specific antigens and tumor-associated antigens are used in DC vaccinations. These antigens can be peptides/proteins, mRNA, or tumor lysates ${ }^{47}$. Thus, DC vaccination appears a safe and feasible strategy; furthermore, the vaccination combines with antigen-specific CTL activity and positive natural killer response in $>50 \%$ cancer patients ${ }^{\mathbf{4 8 , 4 9}}$.

In 2010, sipuleucel-T, the first cellular-based immunotherapy, was approved by USA FDA for the treatment of prostate cancer patients. The intervention was activated DCs by recombinant fusion protein PA2024, the fusion of GM-CSF with prostate antigen, which can be classified as the intersection between first and second generation of DC vaccines. The randomized clinical trial was conducted on 512 patients; sipuleucel-t treatment increased median survival by 4.1 months compared to the placebo group (25.8 months vs. 21.7 months, respectively); however, the treatment failed to achieve better disease progression ${ }^{50}$. Various kinds of cancer also were clinically treated by DCs such as glioblastoma $^{51,52}$, acute myeloid leukemia ${ }^{53,54}$, breast cancer $^{55}$, metastatic colorectal cancer ${ }^{56}$, prostate can$\operatorname{cer}^{57}$, mesothelioma ${ }^{58}$, lung cancer ${ }^{59}$, hepatocellular carcinoma ${ }^{60}$, pancreatic cancer ${ }^{61}$, advanced melanoma ${ }^{62}$, non-small cell lung cancer ${ }^{63}$, bone and soft tissue sarcoma ${ }^{64}$, and myeloma ${ }^{65,66}$.

\section{Collaborative mechanisms of CIKs and DCs in antitumor cells}

Since DC therapy aims to improve host adaptive immune responses, different strategies have been developed harnessing the immune-stimulation effects of DC with effector cell-based immunotherapy ex vivo. Stimulation activity of DCs is through the ability to capture, processing and presenting a tumorassociated antigen (TAAs), which induces specific antitumor responses. The intervention combining DCs and $\mathrm{T}$ cells ex vivo resulted in a lower risk of relapse and metastasis, lower level of T-reg, and increased Th1 polarization in breast cancer patients ${ }^{67}$.

In recent years, several studies have reported that the synergistic antitumor effect of CIK blends with DCs ${ }^{13,21,68}$. The strategy provides the ability to target cancer cells in an MHC-independent manner through CIK cells, while DCs mount an immune response through an MHC-restriction mechanism. Co-culture of CIK and DCs significantly improved the antitumor effect by increasing cytokine IL-12 and IFNg production; the interaction is a TCR-independent mechanism ${ }^{29,69,70}$. Recent studies have proved that DC enhances CIK through cell-cell contact in an MHC-independent manner but by CD40L/CD40; inhibiting CD40L/CD40 interaction abrogates these changes $^{70,71}$. Interaction of DCs and CIK thus alters the expression of several membrane proteins, including upregulation of membrane protein CD28 and CD40L on CIK, which are co-stimulatory signals promoting immune activation. Further, an increase in proliferation and CIK phenotype (including $\mathrm{CD}^{+}, \mathrm{CD}^{+}$, and $\mathrm{CD} 3^{+} \mathrm{CD}^{+} 6^{+}$population) has been observed after co-culture with $\mathrm{DCs}^{72}$. The concomitant of Treg in CIK population also decreases in both cell and mRNA levels after co-culture with 


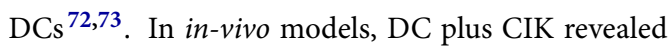
a superior antitumor effect compared to single therapy $^{74}$. The treatment altered host immunity, altering host immune-system composition and augmenting immune antitumor response by enhancing CTL and NK-cell function. The ratio of $\mathrm{CD}^{+} / \mathrm{CD}^{+}$significantly increased after DC/CIK treatment, represented the immunomodulatory effect, and improved immune-surveillance of DC-CIK to the host immune system $^{75,76}$. Also, the level of Th1-associated cytokine was elevated, including IL-2, IFN-g, IL-12. In reverse, the treatment resulted in a lower proportion of immunosuppressive factors, T-reg cell, cytokine IL10 , and TGF- $\beta^{77,78}$.

DCs plus CIKs have been proved as a promising immunotherapy approach in treatment of advanced solid tumors. In a ten-year review, 37 of 85 studies were conducted with DC-CIK treatment for lung cancer, hepatocellular carcinoma, pancreatic cancer, colorectal cancer, renal cell carcinoma, and breast cancer ${ }^{13}$. DC-CIK treatment shows significantly enhanced response rate in patients, better clinical benefit rate, and higher median overall survival compared to conventional treatment group. 
Table 1: Clinical trials of CIK and DC-CIK cells on breast cancer patients

\begin{tabular}{|c|c|c|c|c|c|c|}
\hline Year (Ref) & Study type & Disease & $\begin{array}{l}\text { Patients } \\
\text { (treatment) }\end{array}$ & Pre-treatment & Intervention & Immunotherapy clinical response \\
\hline $2014^{79}$ & Retrospective & $\begin{array}{l}\text { TNBC } \\
\text { (stage I-III) }\end{array}$ & $90(45)$ & $\begin{array}{l}\text { Surgery, adjuvant } \\
\text { chemotherapy with or } \\
\text { without radiation }\end{array}$ & $\begin{array}{l}\text { autologous CIK cells } \\
8.7 \times 10^{9}-1.2 \times 10^{10} \text { cells/cycle } \\
(4-52 \text { cycles })\end{array}$ & $\begin{array}{l}1-, 2-, 3-\text { and } 4 \text {-year DFS rate: } 97.7 \% \text {, } \\
90.1 \%, 83.4 \%, 75.2 \% \text {. } \\
1-, 2-, 3-\text {, and } 4 \text {-year OS rate: } \\
100.0 \%, 100.0 \%, 96.7 \%, 92.4 \% \text {, }\end{array}$ \\
\hline $2018^{80}$ & Retrospective & TNBC & $340(77)$ & Surgery, chemotherapy & $\begin{array}{l}\text { autologous CIK cells } \\
5-7.7 \times 10^{9} \text { cells } / \text { cycle } \\
(1-19 \text { cycles })\end{array}$ & $\begin{array}{l}5 \text {-years OS rate } 94.3 \% \\
5 \text {-year DFS rate } 77.9 \% \\
\text { PD: } 16 / 77 \text { cases }(20.8 \%) \\
\text { Death: } 4 / 77 \text { cases }(5.2 \%)\end{array}$ \\
\hline $2019^{17}$ & Retrospective & $\begin{array}{l}\text { BC } \\
\text { stage I-III }\end{array}$ & 310 & $\begin{array}{l}\text { Surgery with } \\
\text { chemotherapy or } \\
\text { radiotherapy or } \\
\text { endocrino-therapy }\end{array}$ & $\begin{array}{l}\text { autologous CIK } \\
8.7-12 \times 10^{9} \text { cells/cycle } \\
\text { (at least } 4 \text { cycles) }\end{array}$ & $\begin{array}{l}5 \text {-year OS rate: } 85.7 \% \\
\text { 5-year RFS rate: } 80.8 \%\end{array}$ \\
\hline $2019^{81}$ & Retrospective & TBNC & 294 & $\begin{array}{l}\text { Surgery and } \\
\text { chemotherapy }\end{array}$ & $\begin{array}{l}\text { autologous CIK }>5 \mathrm{x} \\
10^{9} \text { cells/cycle }(1-26 \\
\text { cycles })\end{array}$ & $\begin{array}{l}1-, 3-\text {, and } 5 \text {-year DFS rate: } 99.3 \% \text {, } \\
91.8 \%, 99.1 \% \\
1-, 3-\text {, and } 5 \text {-year OS rate } 99.3 \%, 96.6 \% \text {, } \\
93.4 \%\end{array}$ \\
\hline $2015^{82}$ & Clinical trial & $\begin{array}{l}\text { Metastatic } \\
\text { breast cancer }\end{array}$ & 20 & Chemotherapy & $\begin{array}{l}\text { autologous DC and CIK } \\
1 \times 10^{9} \mathrm{CIK} \text { with } 1 \times 10^{7} \mathrm{DCs} \\
\text { per cycle } \\
(8 \text { cycles })\end{array}$ & $\begin{array}{l}\text { CR: } 3 / 20 \text { cases } \\
\text { PR: } 12 / 20 \text { cases } \\
\text { SD: } 2 / 20 \text { cases } \\
\text { PD: } 3 / 20 \text { cases }\end{array}$ \\
\hline $2013^{83}$ & $\begin{array}{l}\text { Randomized } \\
\text { Controlled Trial }\end{array}$ & $\begin{array}{l}\text { Metastatic } \\
\text { breast cancer }\end{array}$ & $\begin{array}{l}166 \\
(87)\end{array}$ & Chemotherapy & $\begin{array}{l}\text { HDC with autologous DC/CIK } \\
\text { ( } 3 \text { cycles })\end{array}$ & $\begin{array}{l}\text { mOS: } 33.1 \text { months } \\
\text { 3-year OS rate: } 20.7 \% \text { ( } 18 / 87 \text { patients). } \\
\text { 4-year OS rate: } 9.2 \% \text { ( } 8 / 87 \text { cases })\end{array}$ \\
\hline $2015^{84}$ & Clinical trial & $\begin{array}{l}\text { Advanced } \\
\text { cancer stage IV }\end{array}$ & $\begin{array}{l}12 \text { cases with } \\
\text { breast cancer }\end{array}$ & $\begin{array}{l}\text { Surgery or } \\
\text { chemotherapy or } \\
\text { radiation }\end{array}$ & $\begin{array}{l}\text { autologous DC/CIK } \\
5.7+2.94 \times 10^{9} \text { cells/cycle } \\
(6 \text { cycles })\end{array}$ & DCR: $25 \%(3 / 12$ cases $)$ \\
\hline
\end{tabular}




\begin{tabular}{|c|c|c|c|c|c|c|}
\hline \multicolumn{7}{|c|}{ Table 1 continued } \\
\hline Year (Ref) & Studytype & Disease & $\begin{array}{l}\text { Patients } \\
\text { (treatment) }\end{array}$ & Pre-treatment & Intervention & Immunotherapy clinical response \\
\hline $2016^{85}$ & Clinical trial & TNBC & 23 & Chemotherapy & $\begin{array}{l}\text { autologous DC/CIK } \\
\text { (3 cycles) }\end{array}$ & $\begin{array}{l}\text { PR: } 3 / 23 \\
\text { SD: } 56.5 \%(13 / 23) \\
\text { PD: } 30.4 \%(7 / 23) \\
\text { ORR: } 13 \% \\
\text { DCR: } 69.6 \% \\
\text { mPFS was } 13.5 \text { months }\end{array}$ \\
\hline $2017^{86}$ & Retrospective & $\begin{array}{l}\text { Stage IV } \\
\text { breast cancer }\end{array}$ & $\begin{array}{l}368 \\
(188)\end{array}$ & Chemotherapy & $\begin{array}{l}\text { autologous DC/CIK } \\
6-10 \times 10^{9} \\
\text { cells/infusion } \\
(4 \text { infusions/cycle, }>3 \text { cycles })\end{array}$ & $\begin{array}{l}5 \text {-year DFS rate: } 42 \% \\
5 \text {-year OS rate: } 44 \%\end{array}$ \\
\hline
\end{tabular}




\section{TRANSPLANTATION OF CIKS AND DCS TO TREAT BREAST CANCER}

\section{Transplantation of CIK cells in the treat- ment of breast cancer}

The clinical approach of CIK-based adoptive cell therapy has been growing vigorously in recent years (Tables 1 and 2). In breast cancer treatment, many patients had enrolled in clinical retrospective studies of CIK immunotherapy.

In 2014, a retrospective study was published by Ke Pan et al. ${ }^{73}$; the study included 90 patients with TNBC status; 45 of them received adjuvant CIK immunotherapy $\left(8.7 \times 10^{9}-1.2 \times 10^{10}\right.$ cells/infusion $)$ after completed chemotherapy without radiation therapy postmastectomy. Following the CIK treatment, TNBC patients experienced better DFS and OS than conventional treatment, using The Kaplan-Meier survival analysis method $(\mathrm{P}=0.0382$ and $\mathrm{P}=0.0046$, respectively). The rate of 1-, 2-, 3-, and 4-year DFS was higher in the CIK treatment group (CIKgroup: $97.7 \%, 90.1 \%, 83.4 \%$, and $75.2 \%$, respectively; control-group: $88.9 \%, 64.4 \%, 62.1 \%$, and $56.4 \%$, respectively). The rate of 1-, 2-, 3-, and 4-year OS was higher in CIK treatment group (CIK-group: 100.0\%, $100.0 \%, 96.7 \%$, and $92.4 \%$, respectively; controlgroup: $95.6 \%, 88.6 \%, 76.3 \%$, and $72.7 \%$, respectively). In further analysis of prognosis in TNBC patients using Cox proportional hazards regression analyses, CIK treatment and disease status were significantly associated with favorable DFS and OS results. According to the Kaplan-Meier analysis result, CIK treatment significantly enhanced OS and DFS advanced-stage group. In contrast, the early-stage TNBC showed no significant difference in response to two treatment types ${ }^{73,87}$. In 2019 , a retrospective on 294 TNBC patients showed that CIK treatment significantly enhanced $1-, 3$-, and 5-year DFS ( $\mathrm{P}=$ $0.047)$ and $O S$ rate $(P=0.007)$ compared to the control group (adjuvant chemotherapy w/o radiation) ${ }^{\mathbf{8 1}}$. Furthermore, the data showed that higher CIK infusion was correlated with a better antitumor effect; more than six cycles of CIK treatment significantly improved DFS $(\mathrm{P}=0.02)$ and OS $(\mathrm{P}=0.04)$. A study on 77 CIK-treated patients similarly concluded that higher cycles $(>6)$ are associated with better prognosis ( $p=0.002$ in DFS, $p=0.024$ in OS) and decreased risk of death ${ }^{87}$. CIK treatment lowered the incidence of metastasis, $16 / 147$ patients in the CIK group compared to $29 / 147$ patients in the control. In the univariate and multivariate analysis, CIK treatment influenced DFS and OS in patients; adjuvant CIK treatment was an independent prognostic factor for both
DFS (HR $=0.520,95 \%$ CI:0.271 $-0.998, \mathrm{P}=0.049)$ and $\mathrm{OS}(\mathrm{HR}=0.414,95 \% \mathrm{CI}: 0.190-0.903, \mathrm{P}=0.027)$ in multivariate analysis. In a study of 310 postoperative breast cancer patients, patients were selected via random table method for the control and the CIK treatment group. The 5-year recurrence-free survival (RFS) rate and the 5-year OS rate were higher in the CIK treatment group than the control (17). In subgroup analysis according to disease type, patients with $\mathrm{ER} / \mathrm{PR}^{+}$and HER ${ }^{-}$significantly benefited from CIK treatment, and significantly prolonged OS was reported. TNBC patients and $\mathrm{ER}^{+} / \mathrm{PR}^{+} / \mathrm{HER} 2^{-}$patients also showed improved prognosis factors; however, those groups were not statistically different. The study found that PD-L1 positive patients experienced better CIK treatment response than PD-L1 negative patients did; significantly higher 5-year RFS (87.6\% versus $76.4 \%, \mathrm{P}=0.048)$ and 5 -year OS (95.2\% versus $77.1 \%, P=0.048 \%$ ) was reported. This effect was reversed in the control treatment group; PD-L1 was correlated with worsened clinical outcomes. Further, negative PD-L1 patients in two cohorts did not statistically differ in RFS and OS, thus suggesting the use of PD-L1 as a biomarker for the adoptive immunotherapy approach for breast cancer patients.

Side effect in these retrospective studies was reported mostly as spontaneous fever; no intolerable or severe side effect was recorded following CIK treatment. Furthermore, no statistical difference was observed in the incidence of adverse effects between the two treatment groups.

\section{Transplantation of DCs in treatment of breast cancer}

In breast cancer treatment, HER-2/neu pulsed DC induced the expression of co-stimulator CD28 on CD8 ${ }^{+}$ $\mathrm{T}$ cells in HER- $2 /$ neu $^{+}$DCIS patients ${ }^{88}$. Additionally, the treatment increased levels of Th1-cytokine IFN-g and induced HER-2/neu-specific $\mathrm{CD}^{+} \mathrm{T}$ cells with a lower level of inhibitory B7 ligand CTLA-4. A high disease-free survival rate and prolonged median disease-free survival were achieved in the vaccinated group, compared to control treatment ${ }^{89}$. P53pulsed DC vaccinations showed $\mathrm{p} 53$-specific $\mathrm{T}$ cell response in advanced breast cancer patients ${ }^{90}$. $\mathrm{Pa}$ tients experienced prolonged survival and temporary regression of metastasis while no toxicity was observed during DC administration. ELISpot analyses analyzed the specific $\mathrm{T}$ cell response; some patients experienced stable disease and lymph node regression. Overall, the clinical efficiency of DC immunotherapy remains below expectations. Poor clinical outcomes result from several factors, including 


\begin{tabular}{|c|c|c|c|c|c|}
\hline Year & Identifier & Phase & Disease & Intervention & Status \\
\hline 2010 & NCT01232062 & not showed & $\begin{array}{l}\text { Breast Neoplasms } \\
\text { Neoplasm Metastasis }\end{array}$ & $\begin{array}{l}\text { High dose } \\
\text { chemotherapy with } \\
\text { DC-CIK }\end{array}$ & Completed \\
\hline 2011 & NCT01395056 & not showed & $\begin{array}{l}\text { Breast Neoplasms } \\
\text { Neoplasm Metastasis }\end{array}$ & $\begin{array}{l}\text { Cyclophosphamide } \\
\text { combined thiotepa } \\
\text { and carboplatin } \\
\text { chemotherapy com- } \\
\text { bined with DC-CIK } \\
\text { immunotherapy }\end{array}$ & Completed \\
\hline 2015 & NCT02491697 & Phase 2 & Breast cancer & $\begin{array}{l}\text { DC-CIK } \\
\text { immunotherapy } \\
\text { with capecitabine }\end{array}$ & $\begin{array}{l}\text { Active, } \\
\text { not recruiting }\end{array}$ \\
\hline 2015 & NCT02539017 & Phase 2 & $\begin{array}{l}\text { Triple Negative Breast } \\
\text { Neoplasms }\end{array}$ & $\begin{array}{l}\text { DC-CIK combined } \\
\text { with chemotherapy }\end{array}$ & Withdrawn \\
\hline 2015 & NCT02450357 & not showed & $\begin{array}{l}\text { Neoplastic Cells, } \\
\text { Circulating }\end{array}$ & $\begin{array}{l}\text { DC-CIK } \\
\text { immunotherapy }\end{array}$ & Completed \\
\hline 2016 & NCT02886897 & $\begin{array}{l}\text { Phase } 1 \\
\text { Phase } 2\end{array}$ & Breast Cancer & $\begin{array}{l}\text { DC-CIK and } \\
\text { anti-PD-1 antibody }\end{array}$ & Unknown \\
\hline 2018 & NCT03524261 & Phase 2 & Advanced breast cancer & $\begin{array}{l}\text { Activated CIK and } \\
\text { CD3-MUC1 } \\
\text { Bispecific Antibody }\end{array}$ & Withdrawn \\
\hline 2020 & NCT04282044 & Phase 1 & $\begin{array}{l}\text { Triple Negative Breast } \\
\text { Cancer } \\
\text { (advanced solid tumors) }\end{array}$ & $\begin{array}{l}\text { CRX100 suspension } \\
\text { (autologous CIK) }\end{array}$ & Recruiting \\
\hline 2020 & NCT04476641 & Phase 2 & Breast cancer & $\begin{array}{l}\text { DC-CIK } \\
\text { immunotherapy }\end{array}$ & Recruiting \\
\hline
\end{tabular}

lack of appropriate target antigens, downregulation of TAA and MHC molecules in tumor cells, poor homing ability of adoptive transferred-DC to lymph node, and rate of inducing target-specific CTL and immunesuppressive tumor microenvironment ${ }^{42}$. However, DC vaccination is a safe approach, thus facilitating further modifications and research to improve the clinical results.

\section{DC-CIK cell transplantation in treatment with breast cancer}

Preclinical studies have proved the superior antitumor effects of DC-combined CIK ${ }^{\mathbf{7 0 , 7 4 , 9 1 , 9 2}}$. DC-CIK combination has been widely used in clinical trials besides chemotherapy for cancer treatment ${ }^{75,93-96}$. Co-culturing DC and CIK leads to greater CIK anticancer effect against cancer cell. In clinical trials, the DC-CIK combination also showed that the clinical response outweighs conventional therapy. In five accessed clinical studies on DC and CIK application, a total of 589 breast cancer patients were enrolled, including 330 patients under DC-CIK treatment. In 2013, Ren J et al. investigated the effect of high-dose chemotherapy and DC-CIK compared to standard dose chemotherapy for metastatic breast cancer treatment in 166 patients ${ }^{83}$. The intervention was two cycles of $120 \mathrm{mg} / \mathrm{m}^{2}$ docetaxel plus $175 \mathrm{mg} / \mathrm{m}^{2}$ thiotepa in combination with DC-CIK; the addition of carboplatin was optional. The trial group achieved a significantly higher objective response rate compared to SDC treatment, $25.9 \%$ versus $10.1 \%$, respectively ( $\mathrm{P}$ $=0.009)$. In summary, $2 \mathrm{CR}$ cases $(2.4 \%), 20 \mathrm{PR}$ (23.5\%) cases, and 42 SD (49.4\%) cases were reported in the HDC+DC-CIK treatment group. The medianOS were double that of the control group, 33.1 months in the experiment group and 15.2 months in the control group $(\mathrm{P}<0.001)$. The median-PFS also significantly improved in the experiment group, with an average of 10.2 months vs. 3.7 months $(\mathrm{P}<0.001)$. In the Cox regression model, HDC plus DC-CIK treatment for HER-2 positive patients with less than three 
metastasis sites were correlated with better OS and PFS prognosis. In the following clinical study in 2016, 23 metastatic pre-treated TNBC patients received a combination of cyclophosphamide, thiotepa, carboplatin, and DC-CIK immunotherapy. The study reported a $13.0 \%$ objective response rate (3 PR cases) and a $69.6 \%$ disease control rate (3 PR cases, 13 SD cases). The median-FPS reached 13.5 months (95\% CI, $10.1-16.9$ months), and the median OS was 15.2 months (95\% CI, 12.5 - 18.1 months) ${ }^{85}$. In 2017, Lin $\mathrm{M}$ et al. published a 10-year follow-up study from 2003-2013. About 368 staged-IV breast cancer patients were recruited, and 188 patients were treated with one cycle of low-dose chemotherapy (Carmofure) and at least three cycles of four DC-CIK infusions ${ }^{86}$. One infusion regimen included $6-9.10^{9}$ DC-CIK cells in $250 \mathrm{ml}$ saline plus $1500 \mathrm{U} / \mathrm{ml} \mathrm{IL-}$ 2 and $1 \%$ human albumin intravenously. Lymphocyte count and function were tested after DC-CIK treatment from chemotherapy treatment. Th1-type cytokine was elevated upon DC-CIK treatment, including IL-2, TNF- $\beta$, and INF- $\gamma$. DC-CIK treatment significantly improved OS and DFS compared to the control group. The 5 -year DFS was $42 \%$ in the experiment group, while that of control group was $30 \%$ (P $<0.01)$. The 5 -year OS was $44 \%$ in the experimental group versus $29 \%$ in the control group $(\mathrm{P}<0.01)$. Additionally, DC-CIK treatment independently lowered the risk of disease progression $(\mathrm{OR}=0.09,95 \% \mathrm{CI}$ $0.02-0.42, \mathrm{P}<0.01)$ and risk of death $(\mathrm{OR}=0.05,95 \%$ CI $0.01-0.37, \mathrm{p}<0.01$ ), according to multivariate Cox proportional regression analysis. DC-CIK treatment represented a feasible cancer treatment strategy with minimal side effects. The most common side effects were related to the chemotherapy. No lethal adverse effects were reported following DC-CIK treatment. Patients have received at least one infusion of DC-CIK; no dose modification or disruption was reported. The most common side effect was fever.

In 2014, a meta-analysis study about DCs, CIKs, and the combination of DC-CIK treatment for breast cancer patients was published by Wang et al. ${ }^{97}$. The meta-analysis study was conducted from 27 clinical trials with 633 enrolled breast cancer patients and compared DCs and CIKs treatment versus nonDC/CIK treatment. According to the analyzed result, the 1-year survival rate of patients in the group was significantly improved $(\mathrm{P}<0.0001)$ for DC/CIK treatment group. Higher rates of 2- and 3-year survival were also reported following DC-CIK treatment; however no significant statistical difference was noted between the two groups (2-year survival: $83 \%$ versus $76 \%, \mathrm{P}=0.07$; 3 -year survival: $64 \%$ versus $48 \%, \mathrm{P}=$
0.07). The Karnofsky Performance Status Scale (KPS) results showed that breast cancer patients significantly improved from DC-CIK treatment compared to nonDC-CIK therapy (OR: 12.40, 95\% CI $=6.61-18.19$, P $<0.0001)$. A higher clinical benefit rate was recorded in DC-CIK group; however, the data was not statistically different. Additionally, the study analyzed host immune response to DC-CIK therapy. Significantly increased proportion of $\mathrm{CD} 3^{+}, \mathrm{CD} 4^{+}, \mathrm{CD} 6^{+}$, $\mathrm{CD}^{+} \mathrm{CD}^{+}, \mathrm{CD}^{+}{ }^{+} \mathrm{CD} 56^{+}$immune cell subsets $(\mathrm{P}<$ $0.00001)$ and enhancement in T cell immunity function (AG-NOR: OR $=0.68, \mathrm{P}<0.0001$ ) were observed after DC-CIK treatment. Several antitumor response cytokines were elevated following DC-CIK treatment, including IL-2, IL-6, IL-12, IFN- $\gamma$, and TNF- $\alpha(\mathrm{P}<$ $0.00001)$. Moreover, the level of serum cancer markers was significantly decreased after DC-CIK treatment. Later, $\mathrm{Hu}$ et al. ${ }^{95}$ published a meta-analysis to compare the efficacy and safety of DC-CIK therapy versus conventional chemotherapy for breast cancer treatment. The study was conducted based on 11 randomized clinical trials with 941 breast cancer patients (including 386 cases who experienced CIK or DC-CIK, 361 cases with conventional chemotherapy only), with no statistical difference between the two groups of patients. Most studies (9/11 studies) reported CR and PR; the difference was significant between the CIK-DC treatment group and the conventional treatment group (CR: $\mathrm{RR}=1.54,95 \% \mathrm{CI}: 1.09$ 2.19; PR: $R R=1.33,95 \%$ CI: $1.11-1.59)$. In the metaanalysis, ORR was reported in 10 studies, significantly different between DC-CIK and conventional groups $(\mathrm{RR}=1.37,95 \% \mathrm{CI}: 1.20-1.57)$. The incidence of side effects was not significant between DC-CIK treatment and non-DC-CIK and conventional treatment groups in both meta-analyses. Side effects included fever, leucocyte decrease, gastrointestinal adverse effects (OR: 0.72, 95\% CI: $0.36-1.45, \mathrm{P}=0.36)^{97}$ and leukopenia, thrombocytopenia, hair loss, nausea/vomiting, hepatic complications, and neurologic complications 95 .

\section{FUTURE PERSPECTIVES}

Current clinical trial data demonstrated that DC$\mathrm{CIK}$ is a promising approach for breast cancer treatment $^{21}$. With chemotherapy's success in improving clinical response, the combination of DC-CIK prolongs survival in breast cancer patients. In a recent study by Ren J et al. in 2013, DC-CIK combined with HDC was used as first-line treatment for metastatic breast cancer patients. Patients experienced delayed disease relapse and longer survival time ${ }^{83}$. Success in the clinical trials attracted research on CIK and 
DC; several strategies have been evaluated in vitro and in vivo. DC-CIK cells efficiently targeted cancer stem cells; autologous CIK cells inhibited tumor growth in PDX models ${ }^{\mathbf{9 1}, 92,98-100}$. Recent studies have focused on modified CIK cells with chimeric antigen receptors to enhance CIK cytotoxic function and cancer-targeting ability $8,101,102$. Ren et al. incorporated CIK cells with anti-EGFR chimeric antigen receptor (CAR); the CAR-CIKs showed superior antitumor target against EGFR-positive tumor cells ${ }^{103}$. The combination of CAR and CIK further enhanced the secretion of IL-2 and IFN-gamma by CIK cells. Besides aiming to modify CIK cells, the combination of CIK cells with commercial immunotherapy drugs is also under investigation. The combination of $\mathrm{mAbs}$ with CIK cells showed promising results in preclinical studies ${ }^{34,36,104}$. It improved cytotoxicity of CIK cells via ADCC and increased infiltrated CIK cells in tumor specimens. The prospective study by Zhou et al. showed that PD-L1 expression in TNBC patients correlated with better response to CIK treatment, thus suggesting the combination of PD-L1/PD1 immunotherapy treatment with CIK cells ${ }^{17}$.

In addition to the traditional autologous approach, among several cell-based immunotherapies, CIK cells are suggested as potential allogeneic cellular immunotherapy capable of approaching an "off-theshelf" strategy (Figure 2). The preclinical trial had demonstrated low GVHD ability of CIK cells: allograft of CIK cells associated with graft-versustumor (GvT) showed minimal graft-versus-hostdisease (GvHD) side effect ${ }^{14,18,19,105}$. The clinical trials showed that allogeneic CIKs after hematopoietic stem cell transplantation (HSCT) showed a low incidence of GvHD in recipients while inducing antitumor response ${ }^{106-108}$. In 2012, Linn et al. reported a clinical trial phase I/II with allogeneic-HSCT relapsed patients; in five patients who developed immune responses attributed to CIK cell infusion, the risk of acute-GvHD was low (3/16 patients) and easily controlled ${ }^{107}$. In the combination of allogeneic CIK with donor lymphocyte infusion (DLI), the incidence of a GVHD was mostly associated with DLI (8 of 12 cases, total $16 \%)^{109}$.

Moreover, umbilical cord blood is an abundant and available source of precursor cells for CIK; more cord blood cells exert low immunogenicity ${ }^{110,111}$. The UCB-CIK cells showed greater proliferation capacity, lower immunogenicity, lower expression of inhibitory receptor PD-1, and less susceptibility to chemotherapy than PB-CIK cells do. Additionally, the UCBCIK cells showed higher production of IFN- $\gamma$ and
IL-2 compared to PB-CIK cells. The antitumor effect was also higher in the UCB-CIK treatment group both in vitro and in vivo ${ }^{112}$. The clinical study further demonstrated the antitumor potential of UCBCIK with minimal toxicities ${ }^{113,114}$.

Further, large-scale production of GMP-grade CIK is under vigorous study; Castiglia $S$ et al. and Palmerini $\mathrm{P}$ et al. suggested the significant impact of culture systems on CIK cell quality ${ }^{115,116}$. Serum-free conditions were studied to abrogate the in-consistent quality of human serum and human pool plasma. A recent study demonstrated the uniformity of cryopreservedCIK cells for up to one year ${ }^{117}$. CryopreservedCIK and cryopreserved PBMC derived-CIK maintained their cytotoxic function toward cancer cells, however, they were lower than freshly-cultured CIK cells ${ }^{117,118}$.

\section{CONCLUSION}

In recent years, immunotherapies for breast cancer treatment have been developed vigorously. The success of DC and CIK in both preclinical and clinical studies demonstrated their position in first-line treatment. Besides, it is worth noting that DC and CIK cells are easily expanded in ex-vivo conditions in GMP with a high expansion rate compared to other adoptive cell therapies. Further, the use of CIK in a clinical trial is IL-2 independent, thus reducing the cytotoxicity of exogenous IL-2. Therefore, the treatment represents a promising approach with safety, tolerability, and minimal toxicity. In breast cancer treatment, the use of DC, CIK, or DC-CIK significantly prolonged the survival of patients, improved quality of life, and increased the patient's immunity function. However, the database was limited to China, the dosage of DCCIK remained heterogeneous, and CIK cells' function depended on donor quality. The clinical reports also showed inconsistent format and bias results. Therefore, it is essential to optimize the procedure of DCCIK therapy to create standard criteria for evaluating DC-CIK. Furthermore, the DC-CIK therapy should be assessed in multi-centered studies on a larger scale and uniform patient disease status.

\section{ABBREVIATIONS}

CAR-T: Chimeric antigen receptor $\mathrm{T}$ cell

CIK: Cytokine induced killer cell

DFS: Disease-free survival

DLI: Donor lymphocyte infusion

GM-CSF: Granulocyte-macrophage colonystimulatin factor

GvHD: Graft-versus-host-disease

GvT: graft-versus-tumor 


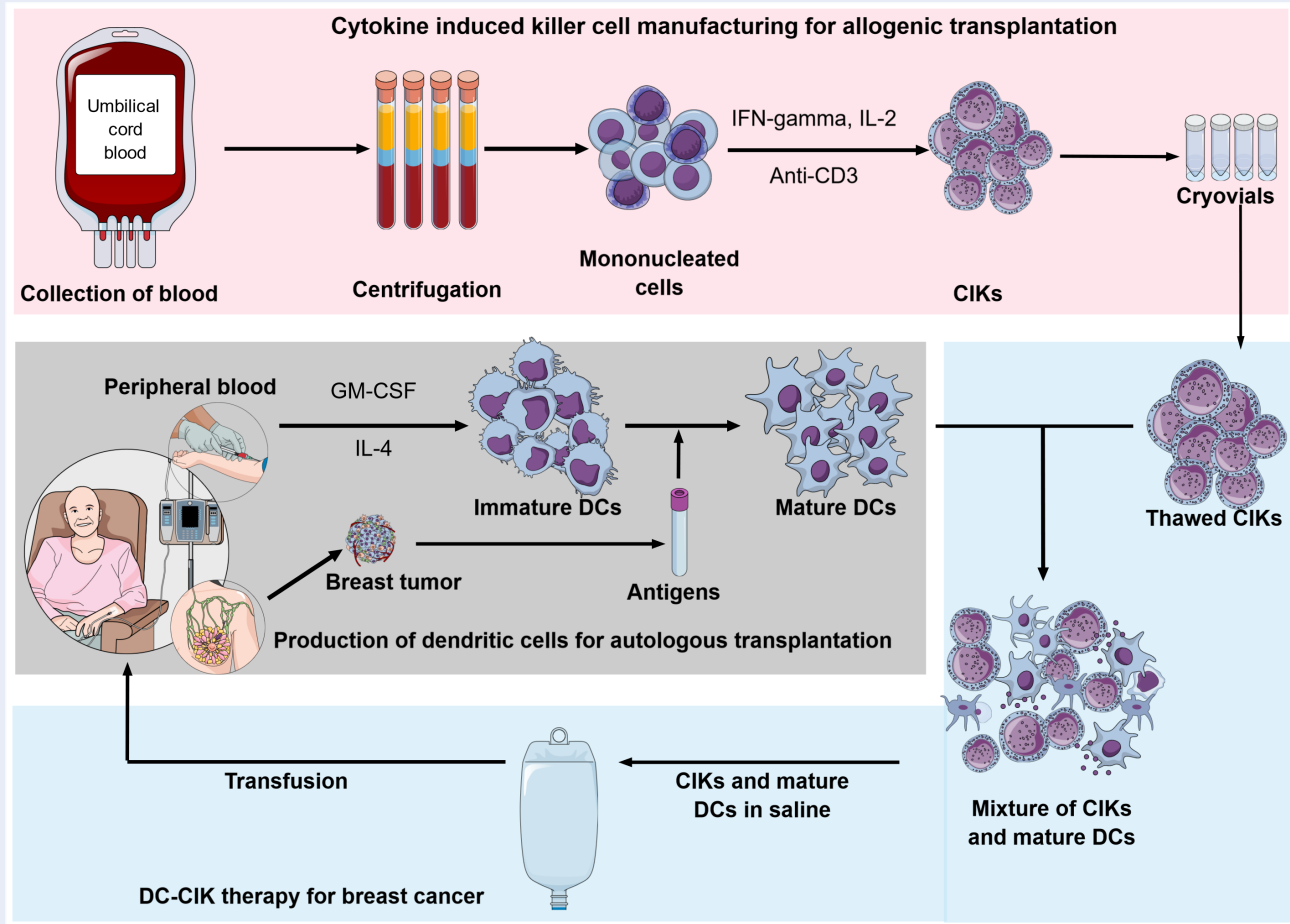

Figure 2: New approach of DC-CIK therapy for breast cancer using autologous dendritic cells and allogenic CIKs. Allogenic CIKs are produced from umbilical cord blood and storaged in freezer until usage. Mature DCs are produced from mononucleated cells derived peripheral blood induced with cytokine (GMCSF, IL-4) and primed with antigens from breast tumors. Thawed CIKs and mature DCs are mixed and incubated before they are used to treating the breast cancer. https://doi.org/10.6084/m9.figshare.17104241.v1

HDC: High-dose chemotherapy

HSCT: Hematopoietic stem cell transplantation

ICAM: Intercellular cell adhesion molecule

IFN: Interferon

IL: Interleukine

LAK: Lymphokine-activated killer cell

MHC: Major histocompatibility complex

MIC A/B: MHC class I-related molecules A and B

NK: Natural killer cell

NKG2D: Natural killer group $2 \mathrm{D}$

OS: Overall survival

PB-CIK: Peripheral blood derived cytokine induced killer cell

PBMC: Peripheral blood mononucleated cell

RFS: Recurrence-free survival

TAAs: Tumor-associated antigen

TBNC: Triple-negative breast cancer

TCR: T-cell receptor

Th1: T helper cell 1

TIL: Tumor-infiltrating lymphocyte

T-reg: Regulatory $\mathrm{T}$ cell

UCB-CIK: Umbilical cord blood derived cytokine induced killer cell
VLA-4: Very late antigen 4

\section{ACKNOWLEDGMENTS}

None.

\section{AUTHOR'S CONTRIBUTIONS}

All authors equally contributed in this work. All authors read and approved the final version of the manuscript for submission.

\section{FUNDING}

This research is funded by Vietnam National University Ho Chi Minh City (VNU-HCM) under grant number C2020-18-26.

\section{AVAILABILITY OF DATA AND MATERIALS}

Not applicable. 


\section{ETHICS APPROVAL AND CONSENT TO PARTICIPATE}

Not applicable.

\section{CONSENT FOR PUBLICATION}

Not applicable.

\section{COMPETING INTERESTS}

The authors declare that they have no competing interests.

\section{REFERENCES}

1. Siegel RL, Miller KD, Jemal A. Cancer statistics, 2019. CA: a Cancer Journal for Clinicians. 2019;69(1):7-34. PMID: 30620402. Available from: $10.3322 /$ caac. 21551.

2. Pham DX, Ho TH, Bui TD, Ho-Pham LT, Nguyen TV. Trends in breast cancer incidence in Ho Chi Minh City 1996-2015: A registry-based study. PLoS One. 2021;16(2):e0246800. PMID: 33566857. Available from: 10.1371/journal.pone. 0246800 .

3. Waldman AD, Fritz JM, Lenardo MJ. A guide to cancer immunotherapy: from $T$ cell basic science to clinical practice. Nature Reviews Immunology. 2020;20(11):651-68. PMID: 32433532. Available from: 10.1038/s41577-020-0306-5.

4. Berraondo P, Sanmamed MF, Ochoa MC, Etxeberria I, Aznar MA, Pérez-Gracia JL. Cytokines in clinical cancer immunotherapy. British Journal of Cancer. 2019;120(1):6-15. PMID: 30413827. Available from: 10.1038/s41416-018-0328y.

5. Pusztai L, Karn T, Safonov A, Abu-Khalaf MM, Bianchini G. New Strategies in Breast Cancer: immunotherapy. Clinical Cancer Research. 2016;22(9):2105-10. PMID: 26867935. Available from: 10.1158/1078-0432.Ccr-15-1315.

6. Restifo NP, Dudley ME, Rosenberg SA. Adoptive immunotherapy for cancer: harnessing the $T$ cell response. Nature Reviews Immunology. 2012;12(4):269-81. PMID: 22437939. Available from: $10.1038 / \mathrm{nri3191.}$

7. Schmidt-Wolf IG, Negrin RS, Kiem HP, Blume KG, Weissman IL. Use of a SCID mouse/human lymphoma model to evaluate cytokine-induced killer cells with potent antitumor cell activity. The Journal of Experimental Medicine. 1991;174(1):139-49. PMID: 1711560. Available from: 10. 1084/jem.174.1.139.

8. Cappuzzello E, Sommaggio R, Zanovello P, Rosato A. Cytokines for the induction of antitumor effectors: the paradigm of Cytokine-Induced Killer (CIK) cells. Cytokine \& Growth Factor Reviews. 2017;36:99-105. PMID: 28629761. Available from: 10.1016/j.cytogfr.2017.06.003.

9. Trinchieri G. Interleukin-12: a cytokine produced by antigenpresenting cells with immunoregulatory functions in the generation of T-helper cells type 1 and cytotoxic lymphocytes. Blood. 1994;84(12):4008-27. PMID: 7994020. Available from: 10.1182/blood.V84.12.4008.bloodjournal84124008.

10. Lopez RD, Waller EK, Lu PH, Negrin RS. CD58/LFA-3 and $\mathrm{IL}-12$ provided by activated monocytes are critical in the in vitro expansion of CD56+ T cells. Cancer Immunology, Immunotherapy. 2001;49(12):629-40. PMID: 11258789. Available from: $10.1007 / \mathrm{s} 002620000148$.

11. Lu PH, Negrin RS. A novel population of expanded human CD3+CD56+ cells derived from $T$ cells with potent in vivo antitumor activity in mice with severe combined immunodeficiency. Journal of immunology (Baltimore, Md : 1950). 1950;153:1687-96.

12. Linn YC, Hui KM. Cytokine-induced killer cells: NK-like T cells with cytotolytic specificity against leukemia. Leukemia \&
Lymphoma. 2003;44(9):1457-62. PMID: 14565644. Available from: 10.3109/10428190309178764.

13. Zhang $Y$, Schmidt-Wolf IG. Ten-year update of the international registry on cytokine-induced killer cells in cancer immunotherapy. Journal of Cellular Physiology. 2020;235(12):9291-303. PMID: 32484595. Available from: $10.1002 /$ jcp. 29827.

14. Sangiolo D, Martinuzzi E, Todorovic M, Vitaggio $K$, Vallario $A$, Jordaney N. Alloreactivity and anti-tumor activity segregate within two distinct subsets of cytokine-induced killer (CIK) cells: implications for their infusion across major HLA barriers. International Immunology. 2008;20(7):841-8. PMID: 18469328. Available from: $10.1093 /$ intimm/dxn042.

15. Franceschetti M, Pievani A, Borleri G, Vago L, Fleischhauer K, Golay J. Cytokine-induced killer cells are terminally differentiated activated CD8 cytotoxic T-EMRA lymphocytes. Experimental Hematology. 2009;37(5). PMID: 19375652. Available from: 10.1016/j.exphem.2009.01.010.

16. Pievani A, Borleri G, Pende D, Moretta L, Rambaldi A, Golay J. Dual-functional capability of CD3+CD56+CIK cells, a T-cell subset that acquires NK function and retains TCR-mediated specific cytotoxicity. Blood. 2011;118(12):3301-10. PMID: 21821703. Available from: 10.1182/blood-2011-02-336321.

17. Zhou ZQ, Zhao JJ, Pan QZ, Chen CL, Liu Y, Tang Y. PD-L1 expression is a predictive biomarker for CIK cell-based immunotherapy in postoperative patients with breast cancer. Journal for Immunotherapy of Cancer. 2019;7(1):228. PMID: 31455411. Available from: 10.1186/s40425-019-0696-8.

18. Nishimura R, Baker J, Beilhack A, Zeiser R, Olson JA, Sega El. In vivo trafficking and survival of cytokine-induced killer cells resulting in minimal GVHD with retention of antitumor activity. Blood. 2008;112(6):2563-74. PMID: 18565854. Available from: 10.1182/blood-2007-06-092817.

19. Baker J, Verneris MR, Ito M, Shizuru JA, Negrin RS. Expansion of cytolytic CD8(+) natural killer T cells with limited capacity for graft-versus-host disease induction due to interferon $\gamma$ production. Blood. 2001;97(10):2923-31. PMID: 11342413. Available from: 10.1182/blood.V97.10.2923.

20. Jiang J, Wu C, Lu B. Cytokine-induced killer cells promote antitumor immunity. J Transl Med. 2013;11:83. PMID: 23536996. Available from: 10.1186/1479-5876-11-83.

21. Garofano F, Gonzalez-Carmona MA, Skowasch D, SchmidtWolf R, Abramian A, Hauser S. Clinical Trials with Combination of Cytokine-Induced Killer Cells and Dendritic Cells for Cancer Therapy. International Journal of Molecular Sciences. 2019;20(17):4307. PMID: 31484350. Available from: 10.3390/ijms20174307.

22. Schmidt-Wolf IG, Lefterova P, Mehta BA, Fernandez LP, Huhn $D$, Blume KG. Phenotypic characterization and identification of effector cells involved in tumor cell recognition of cytokine-induced killer cells. Experimental Hematology. 1993;21(13):1673-9. PMID: 7694868.

23. Schmidt-Wolf IG, Lefterova P, Johnston V, Scheffold C, Csipai M, Mehta BA. Sensitivity of multidrug-resistant tumor cell lines to immunologic effector cells. Cellular Immunology. 1996;169(1):85-90. PMID: 8612299. Available from: 10.1006/cimm.1996.0094.

24. Jamieson AM, Diefenbach A, McMahon CW, Xiong N, Carlyle JR, Raulet $\mathrm{DH}$. The role of the NKG2D immunoreceptor in immune cell activation and natural killing. Immunity. 2002;17(1):19-29. PMID: 12150888. Available from: 10.1016/s1074-7613(02)00333-3.

25. Diefenbach A, Jamieson AM, Liu SD, Shastri N, Raulet DH. Ligands for the murine NKG2D receptor: expression by tumor cells and activation of NK cells and macrophages. Nature Immunology. 2000;1(2):119-26. PMID: 11248803. Available from: $10.1038 / 77793$.

26. Rettinger E, Kuçi S, Naumann I, Becker P, Kreyenberg H, Anzaghe M. The cytotoxic potential of interleukin-15-stimulated cytokine-induced killer cells against leukemia cells. Cytotherapy. 2012;14(1):91-103. PMID: 21973023. Available 
from: 10.3109/14653249.2011.613931.

27. Introna M. CIK as therapeutic agents against tumors. Journal of Autoimmunity. 2017:85:32-44. PMID: 28679475. Available from: 10.1016/j.jaut.2017.06.008.

28. Valgardsdottir R, Capitanio C, Texido G, Pende D, Cantoni C Pesenti E. Direct involvement of CD56 in cytokine-induced killer-mediated lysis of CD56+ hematopoietic target cells. Experimental Hematology. 2014;42(12). PMID: 25201755. Available from: 10.1016/j.exphem.2014.08.005

29. Zhang $Q$, Liu $X Y$, Zhang $T$, Zhang $X F$, Zhao L, Long F. The dual-functional capability of cytokine-induced killer cells and application in tumor immunology. Human Immunology. 2015;76(5):385-91. PMID: 25305457. Available from: 10.1016/j.humimm.2014.09.021.

30. Meng M, Li L, Li R, Wang W, Chen Y, Xie Y. A dynamic transcriptomic atlas of cytokine-induced killer cells. The Journal of Biological Chemistry. 2018;293(51):19600-12. PMID: 30333226. Available from: $10.1074 / \mathrm{jbc}$.RA118.003280.

31. Karimi M, Cao TM, Baker JA, Verneris MR, Soares L, Negrin RS Silencing human NKG2D, DAP10, and DAP12 reduces cytotoxicity of activated CD8+ T cells and NK cells. Journal of immunology (Baltimore, Md : 1950). 2005;175:7819-28. Available from: 10.4049/jimmunol.175.12.7819.

32. Bonanno G, ludicone $P$, Mariotti A, Procoli A, Pandolfi A, Fioravanti D. Thymoglobulin, interferon- $\gamma$ and interleukin2 efficiently expand cytokine-induced killer (CIK) cells in clinical-grade cultures. Journal of Translational Medicine. 2010;8(1):129. PMID: 21138560. Available from: 10.1186/ 1479-5876-8-129.

33. Thorne $\mathrm{SH}$, Negrin RS, Contag $\mathrm{CH}$. Synergistic antitumor effects of immune cell-viral biotherapy. Science. 2006;311(5768):1780-4. PMID: 16556847. Available from: 10.1126/science.1121411.

34. Cappuzzello E, Tosi A, Zanovello P, Sommaggio R, Rosato A. Retargeting cytokine-induced killer cell activity by CD16 engagement with clinical-grade antibodies. Oncoimmunology. 2016;5:e1199311-e. Available from: 10.1080/2162402X. 2016.1199311.

35. Schmidt-Wolf GD, Negrin RS, Schmidt-Wolf IG. Activated T cells and cytokine-induced CD3+CD56+ killer cells. Annals of Hematology. 1997;74(2):51-6. PMID: 9063373. Available from: $10.1007 / \mathrm{s} 002770050257$.

36. Sommaggio R, Cappuzzello E, Pietà AD, Tosi A, Palmerini P, Carpanese D. Adoptive cell therapy of triple negative breast cancer with redirected cytokine-induced killer cells. Oncolmmunology. 2020:9(1):1777046. PMID: 32923140. Available from: 10.1080/2162402x.2020.1777046.

37. Gao X, Mi Y, Guo N, Xu H, Xu L, Gou X. Cytokine-Induced Killer Cells As Pharmacological Tools for Cancer Immunotherapy. Frontiers in Immunology. 2017;8:774. PMID: 28729866. Available from: 10.3389/fimmu.2017.00774.

38. Li XD, Xu B, Wu J, Ji M, Xu BH, Jiang JT, et al. Review of Chinese clinical trials on CIK cell treatment for malignancies. Clinical \& Translational Oncology. 2012;14(2):102-8. PMID: 22301398. Available from: 10.1007/s12094-012-0768-4.

39. Capellero S, Erriquez J, Melano C, Mesiano G, Genta S, Pisacane A. Preclinical immunotherapy with CytokineInduced Killer lymphocytes against epithelial ovarian cancer. Scientific Reports. 2020;10(1):6478. PMID: 32296104. Available from: 10.1038/s41598-020-63634-z.

40. Guo Q, Zhu D, Bu X, Wei X, Li C, Gao D. Efficient killing of radioresistant breast cancer cells by cytokine-induced killer cells. Tumour Biology. 2017;39(3):1010428317695961. PMID: 28349820. Available from: 10.1177/1010428317695961.

41. Anguille S, Smits EL, Bryant C, Acker HHV, Goossens H, Lion E. Dendritic Cells as Pharmacological Tools for Cancer Immunotherapy. Pharmacological Reviews. 2015;67(4):73153. PMID: 26240218. Available from: 10.1124/pr.114.009456.

42. van Gulijk M, Dammeijer F, Aerts JG, Vroman H. Combination Strategies to Optimize Efficacy of Dendritic Cell-Based Immunotherapy. Frontiers in Immunology. 2018:9:2759. PMID: 30568653. Available from: 10.3389/fimmu.2018.02759.
43. Garg AD, Perez MV, Schaaf M, Agostinis P, Zitvogel L, Kroemer G. Trial watch: dendritic cell-based anticancer immunotherapy. Oncolmmunology. 2017;6(7):e1328341. PMID: 28811970. Available from: 10.1080/2162402X.2017. 1328341.

44. Garg AD, Coulie PG, den Eynde BJV, Agostinis P. Integrating Next-Generation Dendritic Cell Vaccines into the Current Cancer Immunotherapy Landscape. Trends in Immunology. 2017;38(8):577-93. PMID: 28610825. Available from: 10.1016/j.it.2017.05.006.

45. Harizi $\mathrm{H}$. Reciprocal crosstalk between dendritic cells and natural killer cells under the effects of PGE2 in immunity and immunopathology. Cellular \& Molecular Immunology. 2013;10(3):213-21. PMID: 23524652. Available from: 10 1038/cmi.2013.1.

46. Mingozzi F, Spreafico R, Gorletta T, Cigni C, Gioia MD, Caccia $M$. Prolonged contact with dendritic cells turns lymph noderesident NK cells into anti-tumor effectors. EMBO Molecular Medicine. 2016;8(9):1039-51. PMID: 27406819. Available from: $10.15252 / \mathrm{emmm} .201506164$

47. Zhou Y, Bosch ML, Salgaller ML, J 25: 289-303 doi: 10 1097/00002371-200207000-00001. Current methods for loading dendritic cells with tumor antigen for the induction of antitumor immunity. 2002;25:289-303. Available from: 10.1097/00002371-200207000-00001.

48. Draube A, Klein-González N, Mattheus S, Brillant C, Hellmich $M$, Engert A. Dendritic cell based tumor vaccination in prostate and renal cell cancer: a systematic review and metaanalysis. PLoS One. 2011;6(4):e18801. PMID: 21533099. Available from: 10.1371/journal.pone.0018801.

49. Lion E, Smits EL, Berneman ZN, Tendeloo VFV. NK cells: key to success of $D C$-based cancer vaccines? The Oncologist. 2012;17(10):1256-70. PMID: 22907975. Available from: 10. 1634/theoncologist.2011-0122.

50. Kantoff PW, Higano CS, Shore ND, Berger ER, Small EJ, Penson $D F$, et al. Sipuleucel-T immunotherapy for castrationresistant prostate cancer. The New England Journal of Medicine. 2010;363(5):411-22. PMID: 20818862. Available from: 10.1056/NEJMoa1001294.

51. Reap EA, Suryadevara CM, Batich KA, Sanchez-Perez L, Archer GE, Schmittling RJ. Dendritic Cells Enhance Polyfunctionality of Adoptively Transferred T Cells That Target Cytomegalovirus in Glioblastoma. Cancer Research. 2018;78(1):256-64. PMID: 29093005. Available from: 10. 1158/0008-5472.Can-17-0469.

52. Batich KA, Reap EA, Archer GE, Sanchez-Perez L, Nair SK, Schmittling RJ. Long-term Survival in Glioblastoma with Cytomegalovirus pp65-Targeted Vaccination. Clinical Cancer Research. 2017;23(8):1898-909. PMID: 28411277. Available from: 10.1158/1078-0432.Ccr-16-2057.

53. Khoury HJ, Collins RH, Blum W, Stiff PS, Elias L, Lebkowski JS. Immune responses and long-term disease recurrence status after telomerase-based dendritic cell immunotherapy in patients with acute myeloid leukemia. Cancer 2017;123(16):3061-72. PMID: 28411378. Available from: $10.1002 /$ cncr.30696.

54. Anguille S, de Velde ALV, Smits EL, Tendeloo VFV, Juliusson $\mathrm{G}$, Cools N. Dendritic cell vaccination as postremission treatment to prevent or delay relapse in acute myeloid leukemia. Blood. 2017;130(15):1713-21. PMID: 28830889. Available from: 10.1182/blood-2017-04-780155.

55. Lowenfeld L, Mick R, Datta J, Xu S, Fitzpatrick E, Fisher CS Dendritic Cell Vaccination Enhances Immune Responses and Induces Regression of HER2pos DCIS Independent of Route: Results of Randomized Selection Design Trial. Clinical Cancer Research. 2017;23(12):2961-71. PMID: 27965306. Available from: 10.1158/1078-0432.Ccr-16-1924.

56. Caballero-Baños M, Benitez-Ribas D, Tabera J, et al. Phase II randomised trial of autologous tumour lysate dendritic cell plus best supportive care compared with best supportive care in pre-treated advanced colorectal cancer pa- 
tients. European journal of cancer (Oxford, England : 1990). 2016;64:167-74. Available from: 10.1016/j.ejca.2016.06.008.

57. Podrazil M, Horvath R, Becht E, Rozkova D, Bilkova P, Sochorova $\mathrm{K}$. Phase I/II clinical trial of dendritic-cell based immunotherapy (DCVAC/PCa) combined with chemotherapy in patients with metastatic, castration-resistant prostate cancer. Oncotarget. 2015;6(20):18192-205. PMID: 26078335. Available from: 10.18632/oncotarget.4145.

58. Aerts JG, de Goeje PL, Cornelissen R, Kaijen-Lambers ME, Bezemer $\mathrm{K}$, van der Leest $\mathrm{CH}$. Autologous Dendritic Cells Pulsed with Allogeneic Tumor Cell Lysate in Mesothelioma: From Mouse to Human. Clinical Cancer Research. 2018;24(4):766-76. PMID: 29233904. Available from: 10. 1158/1078-0432.Ccr-17-2522.

59. Kimura $H$, Matsui $Y$, Ishikawa A, Nakajima T, lizasa T. Randomized controlled phase III trial of adjuvant chemoimmunotherapy with activated cytotoxic $\mathrm{T}$ cells and dendritic cells from regional lymph nodes of patients with lung cancer. Cancer Immunology, Immunotherapy. 2018;67(8):12318. PMID: 29855695. Available from: 10.1007/s00262-0182180-6.

60. Lee JH, Lee $\mathrm{Y}$, Lee $\mathrm{M}$, Heo MK, Song JS, Kim KH. A phase I/lla study of adjuvant immunotherapy with tumour antigenpulsed dendritic cells in patients with hepatocellular carcinoma. British Journal of Cancer. 2015;113(12):1666-76. PMID: 26657650. Available from: 10.1038/bjc.2015.430.

61. Mehrotra S, Britten CD, Chin S, Garrett-Mayer E, Cloud CA, Li $M$, et al. Vaccination with poly(IC:LC) and peptide-pulsed autologous dendritic cells in patients with pancreatic cancer. Journal of Hematology \& Oncology. 2017;10(1):82. PMID: 28388966. Available from: 10.1186/s13045-017-0459-2.

62. Wilgenhof $S$, Corthals J, Heirman C, van Baren N, Lucas S, Kvistborg P. Phase II Study of Autologous MonocyteDerived mRNA Electroporated Dendritic Cells (TriMixDCMEL) Plus Ipilimumab in Patients With Pretreated Advanced Melanoma. Journal of Clinical Oncology. 2016;34(12):13308. PMID: 26926680. Available from: 10.1200/jco.2015.63.4121.

63. Lee JM, Lee MH, Garon E, Goldman JW, Salehi-Rad R, Baratelli FE. Phase I Trial of Intratumoral Injection of CCL21 Gene-Modified Dendritic Cells in Lung Cancer Elicits Tumor-Specific Immune Responses and CD8+ T-cell Infiltration. Clinical Cancer Research. 2017;23(16):4556-68. PMID: 28468947. Available from: 10.1158/1078-0432.Ccr-16-2821.

64. Miwa S, Nishida H, Tanzawa Y, Takeuchi A, Hayashi K, Yamamoto $N$. Phase $1 / 2$ study of immunotherapy with dendritic cells pulsed with autologous tumor lysate in patients with refractory bone and soft tissue sarcoma. Cancer. 2017;123(9):1576-84. PMID: 28241093. Available from: $10.1002 /$ cncr.30606

65. Jung SH, Lee HJ, Lee YK, Yang DH, Kim HJ, Rhee JH. A phase I clinical study of autologous dendritic cell therapy in patients with relapsed or refractory multiple myeloma. Oncotarget. 2017;8(25):41538-48. PMID: 28088784. Available from: 10.18632 /oncotarget. 14582 .

66. Butterfield LH, Zhao F, Lee S, Tarhini AA, Margolin KA, White RL. Immune Correlates of GM-CSF and Melanoma Peptide Vaccination in a Randomized Trial for the Adjuvant Therapy of Resected High-Risk Melanoma (E4697). Clinical Cancer Research. 2017;23(17):5034-43. PMID: 28536308. Available from: 10.1158/1078-0432.Ccr-16-3016.

67. Shevchenko JA, Khristin AA, Kurilin VV, Kuznetsova MS, Blinova DD, Starostina NM, et al. Autologous dendritic cells and activated cytotoxic T cells as combination therapy for breast cancer. Oncology Reports. 2020;43(2):671-80. PMID: 31894312. Available from: 10.3892/or.2019.7435.

68. Wang S, Wang X, Zhou X, Lyerly HK, Morse MA, Ren J. DCCIK as a widely applicable cancer immunotherapy. Expert Opinion on Biological Therapy. 2020;20(6):601-7. PMID: 32033522. Available from: 10.1080/14712598.2020.1728250.

69. Joshi PS, Liu JQ, Wang Y, Chang X, Richards J, Assarsson E, et al. Cytokine-induced killer T cells kill immature dendritic cells by TCR-independent and perforin-dependent mecha- nisms. Cell Development, Growth, Differentiation, and Function. 2006;80:1345-53. Available from: 10.1189/jlb.0506305.

70. Märten A, Ziske C, Schöttker B, et al. Interactions between dendritic cells and cytokine-induced killer cells lead to an activation of both populations. Journal of immunotherapy (Hagerstown, Md : 1997). 2001;24:502-10. Available from: 10.1097/00002371-200111000-00007.

71. Lee HK, Kim YG, Kim JS, Park EJ, Kim B, Park KH. Cytokineinduced killer cells interact with tumor lysate-pulsed dendritic cells via CCR5 signaling. Cancer Letters. 2016;378(2):142-9. PMID: 27216980. Available from: 10.1016/j.canlet.2016.05.020

72. Cao J, Chen C, Wang Y, Chen X, Chen Z, Luo X. Influence of autologous dendritic cells on cytokine-induced killer cell proliferation, cell phenotype and antitumor activity in vitro. Oncology Letters. 2016;12(3):2033-7. PMID: 27602134. Available from: 10.3892/ol.2016.4839.

73. Pan $\mathrm{Y}$, Tao Q, Wang H, Xiong S, Zhang R, Chen T. Dendritic cells decreased the concomitant expanded Tregs and Tregs related IL-35 in cytokine-induced killer cells and increased their cytotoxicity against leukemia cells. PLoS One. 2014;9(4):e93591. PMID: 24705499. Available from: 10.1371/ journal.pone.0093591.

74. Jung NC, Lee JH, Choi HJ, Hwang SU, Song JY, Seo HG. Dendritic Cell Immunotherapy Combined with CytokineInduced Killer Cells Effectively Suppresses Established Hepatocellular Carcinomas in Mice. Immunological Investigations. 2016;45(6):553-65. PMID: 27410037. Available from: 10.1080/08820139.2016.1183025.

75. Mu Y, Zhou CH, Chen SF, Ding J, Zhang YX, Yang YP. Effectiveness and safety of chemotherapy combined with cytokineinduced killer cell /dendritic cell-cytokine-induced killer cell therapy for treatment of gastric cancer in China: A systematic review and meta-analysis. Cytotherapy. 2016;18(9):1162-77. PMID: 27421742. Available from: 10.1016/j.jcyt.2016.05.015.

76. Xiao Z, Wang CQ, Zhou MH, et al. The Antitumor Immunity and Tumor Responses of Chemotherapy with or without DC-CIK for Non-Small-Cell Lung Cancer in China: A MetaAnalysis of 28 Randomized Controlled Trials. J Immunol Res. 2018;2018:9081938. Available from: 10.1155/2018/9081938.

77. Song H, Liu S, Zhao Z, Sun W, Wei X, Ma X. Increased cycles of DC/CIK immunotherapy decreases frequency of Tregs in patients with resected NSCLC. International Immunopharmacology. 2017;52:197-202. PMID: 28941416. Available from: 10.1016/j.intimp.2017.09.014.

78. Zhao X, Ji CY, Liu GQ, Ma DX, Ding HF, Xu M. Immunomodulatory effect of $D C / C I K$ combined with chemotherapy in multiple myeloma and the clinical efficacy. International Journal of Clinical and Experimental Pathology. 2015;8(10):1314655. PMID: 26722513

79. Pan K, Guan XX, Li YQ, Zhao JJ, Li JJ, Qiu HJ, et al. Clinical Activity of Adjuvant Cytokine-Induced Killer Cell Immunotherapy in Patients with Post-Mastectomy Triple-Negative Breast Cancer. Clinical Cancer Research. 2014;20(11):3003-11. PMID: 24668644. Available from: 10.1158/1078-0432.CCR14-0082.

80. Li M, Wang Y, Wei F, An X, Zhang N, Cao S, et al. Journal of breast cancer. 2018;21(2):150-7. Available from: 10.4048/jbc 2018.21.2.150.

81. Zhang Y, Wang S, Yang B, Lu S, Du Y, Liu H. Adjuvant treatment for triple-negative breast cancer: a retrospective study of immunotherapy with autologous cytokine-induced killer cells in 294 patients. Cancer Biology \& Medicine. 2019;16(2):350-60. PMID: 31516755. Available from: 10 . 20892/j.issn.2095-3941.2018.0378.

82. $Q M, L L, C Z, Y S, S L, S C$. Clinical effects of immunotherapy of DC-CIK combined with chemotherapy in treating patients with metastatic breast cancer. Pakistan journal of pharmaceutical sciences. 2015;28(Supplement):1055-58.

83. Ren J, Di L, Song G, et al. Selections of appropriate regimen of high-dose chemotherapy combined with adoptive cellular 
therapy with dendritic and cytokine-induced killer cells improved progression-free and overall survival in patients with metastatic breast cancer: reargument of such contentious therapeutic preferences. Clinical \& translational oncology : official publication of the Federation of Spanish Oncology Societies and of the National Cancer Institute of Mexico. 2013;15:780-8. Available from: 10.1007/s12094-013-1001-9.

84. YJ Z, N J, QK S, JP W, YG S, HM Z, et al. Continuous DC-CIK infusions restore $C D 8+$ cellular immunity, physical activity and improve clinical efficacy in advanced cancer patients unresponsive to conventional treatments. Asian Pacific Journal of Cancer Prevention. 2015;16(6):2419-23. Available from: 10.7314/APJCP.2015.16.6.2419.

85. Wang X, Ren J, Zhang J, et al. Prospective study of cyclophosphamide, thiotepa, carboplatin combined with adoptive DCCIK followed by metronomic cyclophosphamide therapy as salvage treatment for triple negative metastatic breast cancers patients (aged $<45$ ). Clinical \& translational oncology : official publication of the Federation of Spanish Oncology Societies and of the National Cancer Institute of Mexico. 2016;18:82-7. Available from: 10.1007/s12094-015-1339-2.

86. Lin M, Liang S, Jiang F, Xu J, Zhu W, Qian W. 2003-2013, a valuable study: autologous tumor lysate-pulsed dendritic cell immunotherapy with cytokine-induced killer cells improves survival in stage IV breast cancer. Immunology Letters. 2017;183:37-43. PMID: 28143792. Available from: 10.1016/j.imlet.2017.01.014.

87. Golay J, Martinelli S, Alzani R, Cribioli S, Albanese C, Gotti E. Cord blood-derived cytokine-induced killer cells combined with blinatumomab as a therapeutic strategy for CD19+ tumors. Cytotherapy. 2018;20(8):1077-88. PMID: 30093325. Available from: 10.1016/j.jcyt.2018.06.003.

88. Czerniecki BJ, Koski GK, Koldovsky U, Xu S, Cohen PA, Mick R. Targeting HER-2/neu in early breast cancer development using dendritic cells with staged interleukin-12 burst secretion. Cancer Research. 2007;67(4):1842-52. PMID: 17293384. Available from: 10.1158/0008-5472.Can-06-4038.

89. Peoples GE, Gurney JM, Hueman MT, Woll MM, Ryan GB, Storrer CE. Clinical trial results of a HER2/neu (E75) vaccine to prevent recurrence in high-risk breast cancer patients. Journal of Clinical Oncology. 2005;23(30):7536-45. PMID: 16157940. Available from: 10.1200/jco.2005.03.047.

90. Svane IM, Pedersen AE, Johnsen $H E$, Nielsen $D$, Kamby $C$, Gaarsdal E. Vaccination with p53-peptide-pulsed dendritic cells, of patients with advanced breast cancer: report from a phase I study. Cancer Immunology, Immunotherapy. 2004;53(7):633-41. PMID: 14985857. Available from: 10. 1007/s00262-003-0493-5.

91. Qin W, Xiong Y, Chen J, Huang Y, Liu T. DC-CIK cells derived from ovarian cancer patient menstrual blood activate the TNFR1-ASK1-AIP1 pathway to kill autologous ovarian cancer stem cells. Journal of Cellular and Molecular Medicine. 2018;22(7):3364-76. PMID: 29566310. Available from: 10. $1111 / \mathrm{jcmm} .13611$.

92. Yang T, Zhang W, Wang L, Xiao C, Wang L, Gong Y. Co-culture of dendritic cells and cytokine-induced killer cells effectively suppresses liver cancer stem cell growth by inhibiting pathways in the immune system. BMC Cancer. 2018;18(1):984. PMID: 30326865. Available from: 10.1186/s12885-018-4871$y$.

93. Lan XP, Chen YG, Wang Z, Yuan CW, Wang GG, Lu GL. Immunotherapy of DC-CIK cells enhances the efficacy of chemotherapy for solid cancer: a meta-analysis of randomized controlled trials in Chinese patients. Journal of Zhejiang University Science B. 2015;16(9):743-56. PMID: 26365116. Available from: 10.1631/jzus.B1500003.

94. Zhao Y, Qiao G, Wang X, et al. Combination of DC/CIK adoptive $T$ cell immunotherapy with chemotherapy in advanced non-small-cell lung cancer (NSCLC) patients: a prospective patients' preference-based study (PPPS). Clinical \& translational oncology : official publication of the Federation of
Spanish Oncology Societies and of the National Cancer Institute of Mexico. 2019;21:721-8. Available from: 10.1007/ s12094-018-1968-3.

95. Hu J, Hu J, Liu X, Hu C, Li M, Han W. Effect and safety of cytokine-induced killer (CIK) cell immunotherapy in patients with breast cancer: A meta-analysis. Medicine. 2017;96(42):e8310. PMID: 29049237. Available from: 10 1097/md.0000000000008310.

96. Qiao $G$, Wang $X$, Zhou L, Zhou X, Song Y, Wang S. Autologous Dendritic Cell-Cytokine Induced Killer Cell Immunotherapy Combined with S-1 Plus Cisplatin in Patients with Advanced Gastric Cancer: A Prospective Study. Clinical Cancer Research. 2019;25(5):1494-504. PMID: 30514775. Available from: 10.1158/1078-0432.Ccr-18-2360.

97. Wang ZX, Cao JX, Wang M, Li D, Cui YX, Zhang XY. Adoptive cellular immunotherapy for the treatment of patients with breast cancer: a meta-analysis. Cytotherapy. 2014;16(7):93445. PMID: 24794183. Available from: 10.1016/j.jcyt.2014.02. 011.

98. Gammaitoni L, Giraudo L, Macagno M, Leuci V, Mesiano G, Rotolo R. Cytokine-Induced Killer Cells Kill Chemo-surviving Melanoma Cancer Stem Cells. Clinical Cancer Research. 2017;23(9):2277-88. PMID: 27815354. Available from: 10. 1158/1078-0432.CCR-16-1524.

99. Gammaitoni L, Giraudo L, Leuci V, Todorovic M, Mesiano G, Picciotto F. Effective activity of cytokine-induced killer cells against autologous metastatic melanoma including cells with stemness features. Clinical Cancer Research 2013;19(16):4347-58. PMID: 23794732. Available from: 10.1158/1078-0432.Ccr-13-0061.

100. Mesiano G, Grignani G, Fiorino E, et al. Cytokine Induced Killer cells are effective against sarcoma cancer stem cells spared by chemotherapy and target therapy. Oncoimmunology. 2018;7:e1465161-e. Available from: 10.1080/ 2162402X.2018.1465161.

101. Magnani CF, Gaipa G, Belotti D, Matera G, Tettamanti S, Cabiati B. Donor-Derived CD19 CAR Cytokine Induced Killer (CIK) Cells Engineered with Sleeping Beauty Transposon for Relapsed B-Cell Acute Lymphoblastic Leukemia (B-ALL). Blood. 2019;134:200. Available from: 10.1182/blood-2019-125894.

102. Hombach AA, Rappl G, Abken H. Arming cytokine-induced killer cells with chimeric antigen receptors: CD28 outperforms combined CD28-OX40 "super-stimulation". Molecular therapy: the journal of the American Society of Gene Therapy. 2013;21:2268-77. Available from: 10.1038/mt.2013.192.

103. Ren X, Ma W, Lu H, Yuan L, An L, Wang X. Modification of cytokine-induced killer cells with chimeric antigen receptors (CARs) enhances antitumor immunity to epidermal growth factor receptor (EGFR)-positive malignancies. Cancer Immunology, Immunotherapy. 2015;64(12):1517-29. PMID: 26386966. Available from: 10.1007/s00262-015-1757-6.

104. Chen D, Sha H, Hu T, Dong S, Zhang J, Liu S, et al. Cytokineinduced killer cells as a feasible adoptive immunotherapy for the treatment of lung cancer. Cell Death \& Disease. 2018;9(3):366. PMID: 29511158. Available from: 10.1038/ s41419-018-0404-5.

105. Verneris MR, Ito $M$, Baker J, Arshi A, Negrin RS, Shizuru JA. Engineering hematopoietic grafts: purified allogeneic hematopoietic stem cells plus expanded CD8+ NK-T cells in the treatment of lymphoma. Biology of blood and marrow transplantation : journal of the American Society for Blood and Marrow Transplantation. 2001;7:532-42. Available from: 10.1016/s1083-8791(01)70014-6.

106. Tang $\mathrm{O}$, Grzywacz B, Wang $\mathrm{H}$, Kataria N, Cao $\mathrm{O}$, Wagner JE, et al. Adoptive immunotherapy with cytokine-induced killer cells for patients with relapsed hematologic malignancies after allogeneic hematopoietic cell transplantation. Biology of blood and marrow transplantation: journal of the American Society for Blood and Marrow Transplantation. 2008;17:1679-87. Available from: 10.4049/jimmunol.181.7. 4507. 
107. Laport GG, Sheehan K, Baker J, et al. The anti-tumour activity of allogeneic cytokine-induced killer cells in patients who relapse after allogeneic transplant for haematological malignancies. Bone Marrow Transplantation. 2011;47:95766. Available from: 10.1016/j.bbmt.2011.05.012.

108. Linn YC, Niam M, Chu S, Choong A, Yong HX, Heng KK. The anti-tumour activity of allogeneic cytokine-induced killer cells in patients who relapse after allogeneic transplant for haematological malignancies. Bone Marrow Transplantation. 2012;47(7):957-66. PMID: 21986635. Available from: 10.1038/bmt.2011.202.

109. Introna M, Borleri G, Conti E, Franceschetti M, Barbui AM, Broady R. Repeated infusions of donor-derived cytokineinduced killer cells in patients relapsing after allogeneic stem cell transplantation: a phase I study. Haematologica. 2007;92(7):952-9. PMID: 17606446. Available from 10.3324/haematol.11132

110. Introna $M$, Lussana F, Algarotti A, Gotti E, Valgardsdottir R, Micò C. Phase II Study of Sequential Infusion of Donor Lymphocyte Infusion and Cytokine-Induced Killer Cells for Patients Relapsed after Allogeneic Hematopoietic Stem Cell Transplantation. Biology of Blood and Marrow Transplantation. 2017;23(12):2070-8. PMID: 28712935. Available from: 10.1016/j.bbmt.2017.07.005.

111. Introna M, Franceschetti M, Ciocca A, Borleri G, Conti E, Golay J. Rapid and massive expansion of cord blood-derived cytokine-induced killer cells: an innovative proposal for the treatment of leukemia relapse after cord blood transplantation. Bone Marrow Transplantation. 2006;38(9):621-7. PMID: 16980990. Available from: 10.1038/sj.bmt.1705503.

112. Zhang Z, Zhao X, Zhang T, Wang L, Yang L, Huang L. Phenotypic characterization and anti-tumor effects of cytokineinduced killer cells derived from cord blood. Cytotherapy. 2015;17(1):86-97. PMID: 25457278. Available from: 10.1016/ j.jcyt.2014.09.006.

113. Zhang Z, Wang L, Luo Z, Zhao X, Huang J, Li H. Efficacy and safety of cord blood-derived cytokine-induced killer cells in treatment of patients with malignancies. Cytotherapy. 2015;17(8):1130-8. PMID: 25963952. Available from: 10 . 1016/j.jcyt.2015.04.002.

114. Wang L, Huang S, Dang Y, Li M, Bai W, Zhong Z. Cord bloodderived cytokine-induced killer cellular therapy plus radiation therapy for esophageal cancer: a case report. Medicine. 2014;93(28):e340. PMID: 25526496. Available from: 10.1097/ md.0000000000000340.

115. Castiglia S, Adamini A, Rustichelli D, Castello L, Mareschi K, Pinnetta G. Cytokines induced killer cells produced in good manufacturing practices conditions: identification of the most advantageous and safest expansion method in terms of viability, cellular growth and identity. Journal of Translational Medicine. 2018;16(1):237. PMID: 30157948. Available from: 10.1186/s12967-018-1613-5.

116. Palmerini $P$, Pietà $A D$, Sommaggio $R$, Ventura $A$, Astori $G$, Chieregato K. A serum-free protocol for the ex vivo expansion of Cytokine-Induced Killer cells using gas-permeable static culture flasks. Cytotherapy. 2020;22(9):511-8. PMID: 32631696. Available from: 10.1016/j.jcyt.2020.05.003.

117. Mareschi K, Adamini A, Castiglia S, Rustichelli D, Castello L, Mandese A. Cytokine-Induced Killer (CIK) Cells, In Vitro Expanded under Good Manufacturing Process (GMP) Conditions, Remain Stable over Time after Cryopreservation. Pharmaceuticals (Basel, Switzerland). 2020;13(5):93. PMID: 32408620. Available from: 10.3390/ph13050093.

118. Liang $X, \mathrm{Hu} X, \mathrm{Hu} Y$, Zeng $W$, Zeng $G$, Ren $Y$. Recovery and functionality of cryopreserved peripheral blood mononuclear cells using five different xeno-free cryoprotective solutions. Cryobiology. 2019;86:25-32. PMID: 30629948. Available from: 10.1016/j.cryobiol.2019.01.004 
Ready to submit your manuscript? Choose Biomedpress and benefit from:

- Fast, convenient online submission

- Through peer-review by experienced researchers

- Rapid publication on acceptance

- Free of charge (without publication fees)

Learn more http://www.biomedpress.org/journals/
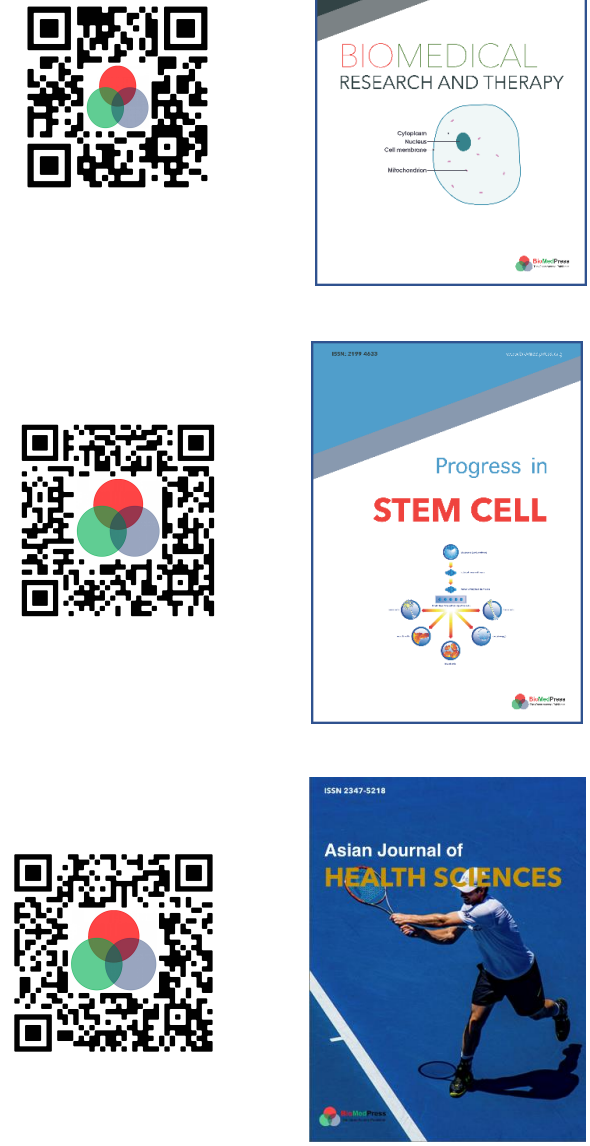

Asian Journal of Health Sciences

ISSN: 2347-5218

Indexed: Google Scholar

Acceptance Rate (2020): 72.89\%

Article Publishing Charge: Free

Submission to first editorial decision: 16.5 days

Biotechnological Research

ISSN: 2395-6763

Indexed: Google Scholar

Acceptance Rate (2020): $67.02 \%$

Article Publishing Charge: Free

Submission to first editorial decision: 28.5 days 